\title{
Moschatel Press: Craft, Concrete, and Constructivism in the Cotswolds
}

The author confirms that this article has not been published elsewhere and has not been submitted simultaneously for publication elsewhere.

\section{Key words}

Thomas A. Clark, Laurie Clark, Moschatel Press; Arts and Crafts Movement, constructivism, concrete art, concrete poetry, publishing

\section{Abstract}

In 1973 in the Gloucestershire town of Nailsworth, the poet Thomas A. Clark and the artist Laurie Clark established their own small publishing imprint, Moschatel Press. Despite early titles by, among others, Ian Hamilton Finlay and Cid Corman, Moschatel Press has, primarily, published the Clarks' own work, much of which is collaborative. Utilizing simple formats such as postcards, folding cards, pamphlets, and chapbooks, Moschatel Press publications have explored the indivisible relationship that exists between the printed format - its design and construction-and the expressive and material conditions of text and image. It is perhaps not surprising therefore that the press has been frequently associated with concrete and post-concrete poetry. However, prompted by the press's Cotswolds provenance, this article extends this perspective by examining the ways in which the Arts and Crafts Movement's close associations with the Cotswolds have shaped the Clarks' publishing practices and poetics. In particular, this article considers how the Clarks' early Moschatel Press publications have evoked the Arts and Crafts Movement's commitment to honest design, formal simplicity, and purity. It also addresses how the Clarks have synthesized and confused these key principles of the Arts and Crafts Movement with 
notions of making, construction, and sincerity that inform avant-garde notions of "constructivism" in literature and visual art. In doing so, this article claims that the Clarks' Moschatel Press encourages new ways of thinking about these seemingly antithetical milieus and their relevance in a long and enduring tradition of independent publishing in which Moschatel Press itself remains a formative model and inspirational touchstone.

Ross Hair is a Senior Lecturer in American Studies at the University of East Anglia, UK. He is the author of Avant-Folk: Small Press Poetry Networks from 1950 to the Present (Liverpool University Press, 2016), Ronald Johnson's Modernist Collage Poetry (Palgrave Macmillan, 2010) and, with Thomas Ruys Smith, co-editor of Harry Smith's Anthology of American Folk Music: America Changed Through Music (Routledge, 2016). 


\section{Moschatel Press: Crafts and Constructivism in the Cotswolds}

Remembering the loose collective of poets and artists located in the county of Gloucestershire known as "the Gloup" (the Gloucestershire Group), Thomas A. Clark writes that, "Not since Gimson and the Barnsleys had the Cotsworlds contributed so much to the art of its time."1 Active during the mid 1960s, the Gloup-which included John and Astrid Furnival, Kenelm Cox, Dom Sylvester Houédard, and Charles Verey-was a prominent outpost of the international concrete poetry movement which, according to Clark, was committed to a "rediscovery of the preGutenberg fusion of the writer and the visual artist, the collaboration of author, painter, and typographer towards the realization of the world as physical presence."2 It is perhaps surprising that Clark should, in this context, invoke the names of three furniture designers, architects, and craftsmen-Ernest Gimson and the brothers Ernest and Sidney Barnsley-who were prominent figures in the Cotswold Arts and Crafts Movement in the late nineteenth and early twentieth centuries.

At the core of the Arts and Craft Movement was a reformist attitude to architectural design and the decorative arts that emphasized craft as an antidote to mass-produced industrial manufacture and embellished design. W. R. Lethaby, a renowned architect and designer who influenced the Movement, writing in his book Architecture, Mysticism and Myth (1891) invokes "sweetness, simplicity, freedom,

\footnotetext{
${ }^{1}$ Thomas A. Clark, "Foreword," in Ken Cox: Celebrating A Life's Work 1927-1968

(Gloucestershire: Family of Ken Cox, 2007), n.p.

${ }^{2}$ Thomas A. Clark, “Openings Press: An Appreciation and Bibliography," Ceolfrith 14 (1971): 6-11, at 6.
} 
confidence, and light" as the standards of modern architectural design. ${ }^{3}$ These qualities capture the prevailing sentiments of the Movement, both in theory and praxis, and Lethaby's belief that architecture should be "the synthesis of the fine arts [and] the commune of all the crafts," adumbrates the Movement's wider aspirations to reunite the arts and craft practices and level longstanding hierarchical distinctions between fine and applied art. ${ }^{4}$

As well as esteeming craft with the dignity of the fine arts, the Movement placed considerable importance on the material and medium used by the craftsperson. Mary Greensted describes this reflective approach to material in the construction of furniture, jewelry, and tableware as one of "honesty":

In practice, this involved a concentration on simple lines, surface textures and the extension of constructional details to decoration. There was also a strong element of national pride running through the Movement which found its expression in a love of nature and English traditions. Finally, and possibly most crucial of all to the Arts and Crafts Movement was the idea that creative manual work could provide personal fulfillment. ${ }^{5}$

Nature also influenced wallpaper and textile design, as well as architectural lead and plasterwork, with natural plant and bird motifs being especially popular.

\footnotetext{
${ }^{3}$ W. R. Lethaby, Architecture, Mysticism and Myth (New York: Macmillan, \& Co., 1892), 8 .

${ }^{4}$ Ibid., 1.

${ }^{5}$ Mary Greensted, The Arts and Crafts Movement in the Cotswolds (Stroud: Alan Sutton, 1996), 2.
} 
Natural motifs also decorated the pages of the books published by the numerous private presses that burgeoned as a corollary of the Movement's ethos of meaningful craft and labour. Notwithstanding their different aesthetics, presses such as William Morris's Kelmscott Press and T. J. Cobden-Sanderson's and Emery Walker's Doves Press shared a concern with reviving the craft of book making and design, placing considerable importance on hand-made paper, high quality ink, and bespoke typefaces. Morris was also concerned with "the architectural arrangement" of the book. ${ }^{6}$ Clear readable pages, legible type, proportional use of margins, and a "lateral spacing of words (the whites between them)"- as well as an architectural use of ornament or illustration that "must form as much a part of the page as the type itself"-were his priorities. $^{7}$

It was toward the end of the nineteenth-century, Greensted writes, that the Cotswolds became "synonymous with craftsmanship." ${ }^{\prime 8}$ This association, however, was not entirely unprecedented. Morris had already made the Cotswolds his summer residence in 1871 after acquiring, with Dante Gabriel Rossetti, the lease of the seventeenth-century Kelmscott Manor in the West Oxfordshire village of Kelmscott. Morris's Cotswold residence exerted considerable influence on his work. As well as featuring in his utopian novel News From Nowhere (1890), the manor house lent its name to his London residence, Kelmscott House, and his Kelmscott Press, both of which were based in Hammersmith.

Drawn by the region's natural beauty, architecture, and rural craft traditions, a raft of architects, designers, and craftspeople moved to the Cotswolds in Morris's

\footnotetext{
${ }^{6}$ William Morris, The Ideal Book (London: L.C.C. School of Arts \& Crafts, 1908), 2

${ }^{7}$ Ibid., 2-4, 12-13.

${ }^{8}$ Greensted, The Arts and Crafts Movement in the Cotswolds, 1.
} 
wake. This included Gimson and the Barnsley brothers who were "determined to live like country folk," "draw from nature at first hand and find fresh inspiration from [the] vernacular architecture and traditional crafts" particular to the Cotswolds. ${ }^{9}$ Subsequently, the Cotswolds hosted a number of Arts and Craft guilds and workshops including the small furniture workshop established by Gimson and the Barnsleys near the village of Sapperton and C. R. Ashbee's Guild of Handicraft in Chipping Camden.

Although Furnival claims that, "in truth, it had never really existed," the Gloup (the name was coined by the American poet and publisher Jonathan Williams) would make Gloucestershire, if not the Cotswolds, synonymous with a vibrant milieu of what Houédard called "kinetic eyear poetry." ${ }^{10}$ Working across medias and disciplines (poetry, painting, sculpture, print, and publishing) the Gloup's activities strike a sympathetic chord with the catholic interests of the Arts and Crafts Movement. Additionally, like the Movement, the Gloup's local activities acquired an international standing. This reputation was built on international exhibitions such as the 1966 Arlington-Une, organized in the historic Arlington Mill, a former cloth and corn mill situated near the village of Bibury ("the most beautiful village in England," according to Morris) that Charles Verey's father, the architectural historian David

\footnotetext{
${ }^{9}$ Ibid., 22, 24.

${ }^{10}$ John Furnival, “Openings,” Baseline 18 (1994): 34-38, at 38. Dom Sylvester
} Houédard, "intro to the catalogue of artlington-une" Ceolfrith 15 (1972): 56-58, at 56. Mike Weaver categorises three types of concrete poetry similar to Houédard's in his essay "Concrete Poetry" in terms of "the optic," "the kinetic," and "the phonic." Mike Weaver, “Concrete Poetry," Journal of Typographic Research 1 (1967): 293-326, at 294. 
Verey, purchased in $1965 .{ }^{11}$ Verey's conversion of the Mill into "a museum of arts and crafts, and Victoriana," meant that concrete poetry would often be exhibited in the proximity of the local farm implements, Gimson furniture, and Samuel Palmer etchings collected by Verey. ${ }^{12}$ In addition to the Arlington exhibitions, Houédard's and Furnival's Openings Press, which they established in 1964, helped galvanize the Gloup and put it "at the centre of the Concrete Poetry movement" by publishing some of the most prominent figures in concrete poetry, including Ian Hamilton Finlay, bpNichol, and Hansjörg Mayer. ${ }^{13}$

Neither the Arts and Crafts Movement nor its figureheads such as Morris and John Ruskin are normally cited as influences on concrete poetry. Despite Morris's preoccupations with "The Ideal Book," it is his French contemporary Stéphane Mallarmé who is invariably invoked as the forerunner of concrete poetry and, more broadly, modernist literary and typographical experimentation. In their 1958 essay, "Pilot Plan For Concrete Poetry," Augusto de Campos, Decio Pignatari, and Haroldo de Campos claim Mallarmé's Un coup de dés as making "the first qualitative jump: 'subdivisions prismatiques de l'idée'; space ('blancs') and typographical devices as substantive elements of composition." ${ }^{14}$ To give a more recent example, Kenneth Goldsmith reiterates this genealogy, proposing that, “concrete poetry's modernist

${ }^{11}$ William Morris. The Collected Letters of William Morris, ed. Kelvin Norman, vol. 3 of 4, 1889-1892 (Princeton, NJ: Princeton University Press, 1996), 188.

${ }^{12}$ David Verey, A Shell Guide: Gloucestershire (London: Faber \& Faber, 1970), 48.

${ }^{13}$ Clark, "Foreword," n.p.

${ }^{14}$ Augusto de Campos, Haroldo de Campos, and Decio Pignatari, "Pilot Plan," in Mary Ellen Solt, Concrete Poetry: A World View (Bloomington: Indiana University Press, 1968), 71-72, at 71. 
roots date back to Stéphane Mallarmé's Un coup de dés." ${ }^{\text {15 }}$ Mallarmé's poem is considered as being especially significant because, as Anna Sigrídur Arnar notes, of the unprecedented ways in which it consciously brought together and exploited "the linguistic and plastic dimension of language as well as the abstract utterances of text with its material presentation."16

Compared to Mallarmé, Johanna Drucker suggests, "Morris's own romanticization of outmoded forms (prose, verse, decoration) became a confining limit on his imagination" which, for the contemporary reader, makes his aesthetic seem "retrospective [and] retrograde." " Jerome McGann, however, recognizes these same qualities as making "a profound" and "deeply influential precursive event" for the development of twentieth-century modernist literary and publishing practices. ${ }^{18}$ McGann persuasively argues that Morris's books of poetry published by the Kelmscott Press are "the forbears not merely of early modernist procedures like imagism, vorticism, and objectivism, but of important later developments in visual and concrete poetry." ${ }^{19}$ McGann's assessment of Morris finds a parallel with Nikolaus

${ }^{15}$ Kenneth Goldsmith, Uncreative Writing: Managing Literature in the Digital Age (New York: Columbia University Press, 2011), 37.

${ }^{16}$ Anna Sigrídur Anar, The Book as Instrument: Stéphane Mallarmé, the Artist's Book, and the Transformation of Print Culture (Chicago: The University of Chicago Press, 2011), 168.

${ }^{17}$ Johanna Drucker, The Century of Artists'Books (New York City: Granary Books, 2004), 29.

${ }^{18}$ Jerome McGann, Black Riders: The Visible Language of Modernism (Princeton, NJ: Princeton University Press, 1993), 74-75.

${ }^{19}$ Ibid., 69. 
Pevsner's thesis in Pioneers of Modern Design that Morris, in the spheres of architecture, design, and art, "laid the foundations of the modern style" which would find its fullest realization in the work of Morris "follower" and Bauhaus founder, Walter Gropius. $^{20}$

Whereas Pevsner singles out Morris's "clean and sober designs," "logical unity of composition," and "close study of growth in nature," McGann's claims for Morris's modern style are based on the "typographically rendered poetry" of the Kelmscott editions of Morris's books such as Poems by the Way (1891) and The Earthly Paradise (1896-1897). ${ }^{21}$ These draw "attention to every level and feature of [their] construction," making these particular editions of Morris's poetry "extremely concrete and extremely reflexive." 22 They "put a frame around romantic writing," McGann contends, and introduce "important constructivist and reflexive elements to the scene of textuality" in advance of modernism's more explicit "writerly exploitation of the spatial field of the printed page and codex form." 23

Essentially, the Kelmscott editions foreground Morris's poetry as poiein (making), giving it a "“quoted' or secondary status" with its primary subject "poetry itself - or more particularly, poetry as it may be carried out in an age of capitalist mechanical reproduction." ${ }^{24}$ While this "secondary status" is not as explicit in other

${ }^{20}$ Nikolaus Pevsner, Pioneers of Modern Design: From William Morris to Walter Gropius (Harmondsworth: Penguin, 1975), 39.

${ }^{21}$ Ibid., 53. McGann, Black Riders, 46.

${ }^{22}$ Ibid., 74.

${ }^{23}$ Ibid., 21.

${ }^{24}$ Ibid., 46. 
editions of his poetry, McGann insists that it is characteristic of Morris's broader activities as a designer, printer, and painter:

The fabrics, the furniture, the books, the pictures, the poetry: by coming forward as explicitly as imitations, all this work announced itself as what modernism would later call "constructivist." In every case the fundamental subject is the craft and the art of making which is brought to one's attention through the work as imitation. ${ }^{25}$

\section{From constructivism to concrete}

McGann does not elaborate on what he means specifically by "constructivist," a term that he uses throughout Black Riders to evoke "modernism's constructivist line (Pound, Williams, Stein, Oppen, Zukofsky) which emphasized the word-as-such.,"26 Echoing the emphasis that McGann puts on constructivism as a reflexive practice, Barrett Watten, in The Constructivist Moment, uses the term "constructive aesthetics" to denote an "imperative in radical literature and art to foreground their formal construction. ${ }^{, 27}$ Despite being "an important point of departure" for his readings of, among others, Stein and Zukofsky, Watten is keen to stress that neither Soviet Constructivism, or "the formalist abstraction known as International Constructivism"

\footnotetext{
${ }^{25}$ McGann, Black Riders, 46.

26 Ibid., 134.

${ }^{27}$ Barrett Watten, The Constructivist Moment: From Material Text to Cultural Poetics (Middleton, CT: Wesleyan University Press, 2003), xv.
} 
that proceeded it, constitutes in his constructivist readings "a baseline tradition to which everything refers." 28

The kind of formal construction that Watten and McGann imply is evident in William Carlos Williams's introduction to The Wedge (1944) when he describes the poem as a machine "pruned to perfect economy." 29 "There's nothing sentimental about a machine," Williams claims:

A poem is a small (or large) machine made of words. When I say there's nothing sentimental about a poem I mean that there can be no part, as in any other machine, that is redundant. ${ }^{30}$

Like a machine, Williams implies, a poem should be constructed rather than articulated. Furthermore, each part in its construction is necessary, not superfluous, to its functional purpose. The poet therefore makes and constructs rather than expresses. "It isn't what he says that counts as a work of art," Williams remarks of the poet, "it's what he makes, with such intensity of perception that it lives with an intrinsic movement of its own to verify its authenticity." ${ }^{31}$ Rather than serving as the expressive mouthpiece of the poet's subjective experiences, the poem assumes a degree of formal autonomy and acquires the status of an object among other objects.

In his lecture on Wallace Stevens, Louis Zukofsky makes a similar case for

\footnotetext{
${ }^{28}$ Ibid., xviii.

${ }^{29}$ William Carlos Williams, Collected Poems II: 1939-1962, ed. Christopher MacGowan (Manchester: Carcanet, 2000), 54.

${ }^{30}$ Ibid., 54.

${ }^{31}$ Ibid., 54.
} 
objective form from the perspective of the reader. "I try not read into things," Zukofsky writes: "I try to read which means if the page doesn't have it any imagination on my part as to what I might read into it has no significance."32 "This activity" he suggests, "is a kind of mathematics but more sensuous, and it has little to do with learning, it has something to do with structure."33

The emphasis placed by Williams and Zukofsky on what the poet constructs rather than what she or he says, and their rejection of subjective depth in favour of surface and literality, is echoed in the German writer Max Bense's conception of concrete poetry. Initially published in his and Elisabeth Walther's booklet series edition rot in 1965, Bense proposes:

The word is not used primarily as an intentional carrier of meaning. Beyond that it is used as a material element of construction in such a way that meaning and structure reciprocally express and determine each other. ${ }^{34}$

One of the pioneering figures of concrete poetry, Eugen Gomringer, writing in 1956, proposes that the concrete poem "will not serve as a valve for the release of all sorts of emotions and ideas but will consist of a linguistic structure closely related to

\footnotetext{
${ }^{32}$ Louis Zukofsky, Prepositions +: The Collected Critical Essays (Middletown, CT:

Wesleyan University Press, 2000), 24.

${ }^{33}$ Ibid., 24.

${ }^{34}$ Max Bense, "Concrete Poetry," trans. Irène Montjoye Sinor, in Mary Ellen Solt, Concrete Poetry: A World View (Bloomington: Indiana University Press, 1968), 73, at
} 73. 
the tasks of modern communication. ${ }^{" 35}$ Elaborating on these implications, Bense argues that, "it is the constructive principle of concrete poetry alone which uncovers the material wealth of language." ${ }^{36}$ Therefore the concrete poem is, according to

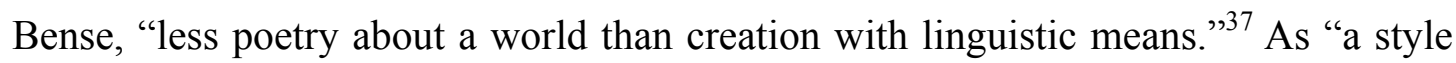
of material poetry," the concrete poem is a "communication scheme [that] serves less an understanding of meaning than an understanding of arrangements"—of "sounds, syllables, words, word sequences and the interdependence of words of all kinds"that are "independent of and not representative of an object extrinsic to language or a world of events. ${ }^{38}$ Not unlike Williams's "machine made of words," the concrete poem is constructed on the grounds that, as Gomringer proposes, "Language with its building elements and rules is intelligible as an object." 39

It is perhaps not surprising that Gomringer-a former secretary of the Swiss artist, architect, and designer Max Bill at the Ulm School of Design in Germany (where Bense also taught)—wanted concrete poetry to "relate literature as art less to

${ }^{35}$ Eugen Gomringer, "Concrete Poetry," trans. Irène Montjoye Sinor, in Mary Ellen Solt, Concrete Poetry: A World View (Bloomington: Indiana University Press, 1968), 67-68, at 67-68.

${ }^{36}$ Bense, "Concrete Poetry," 73.

${ }^{37}$ Max Bense, "Concrete Poetry (II), trans. Irène Montjoye Sinor, in Mary Ellen Solt, Concrete Poetry: A World View (Bloomington: Indiana University Press, 1968), 73 74 , at 73 .

${ }^{38}$ Ibid., 73.

${ }^{39}$ Eugen Gomringer, "Max Bill and Concrete Poetry,” trans. Irène Montjoye Sinor, in Mary Ellen Solt, Concrete Poetry: A World View (Bloomington: Indiana University Press, 1968), 68-69, at 68. 
'literature' and more to earlier developments in the fields of architecture, painting, sculpture, industrial design - in other words to developments whose basis is critical but positively-defined thinking." 40 As Bense's use of terms such as "structure," "construction" and "constructive" would imply, and as Gomringer's emphasis on language as material components also suggests, constructivism was an important development in all the fields that Gomringer mentions-architecture, painting, sculpture, industrial design — and was especially instructive for concrete poetry. Thus, when Gomringer insists that the concrete poem is "a reality in itself and not a poem about something or other," he is reiterating some of the basic tenets underpinning a distinctive constructivist line of nonfigurative art. ${ }^{41}$

Emerging out of the vibrant avant-garde milieu that flourished in Russia in the early decades of the twentieth century, Soviet Constructivist painting and sculptureas pioneered by, among others, Vladimir Tatlin, Naum Gabo, Varvara Stepanova, and Alexander Rodchenko-subsequently became synthesized with other art movements outside of Russia, particularly the Dutch De Stijl movement spearheaded by Theo Van Doesburg and Piet Mondrian. Constructivism, as Daniel Herwitz summarises, "set an example of clarity of vision and formal purity in art" that, in conjunction with the emphasis it placed on "on art as a process of abstract construction from basic

${ }^{40}$ Eugen Gomringer, "The Poem as Functional Object," trans. Irène Montjoye Sinor, in Mary Ellen Solt, Concrete Poetry: A World View (Bloomington: Indiana University Press, 1968), 69-70, at 70

${ }^{41}$ Eugen Gomringer, "From Line to Constellation," trans. Mike Weaver, in Mary Ellen Solt, Concrete Poetry: A World View (Bloomington: Indiana University Press, 1968), 67, at 67. 
designs materials and form," appealed to a number of artists seeking to enforce the idea of art, as universal, nonreferential, and autonomous. ${ }^{42}$

The emphasis that constructivism put on clarity, purity, and autonomy was especially influential for a number of artists in the decades following World War I who were keen to convey "the physical coextension of artistic objects, processes, and media with the actual world." ${ }^{43}$ Artists including Van Doesburg, as Kristine Stiles explains, adopted the term "concrete" in order to differentiate their nonfigurative styles from the more common appellation, "abstract," and its suggestion of "metaphorical representations of nature." 44 "Declaring a work of art to be concrete was, in essence," Alistair Rider suggests, "a way of emphasising the particularity and facticity of the art object as an object, rich in sensual immediacy." 45 Consequently, "the artist's goal is not abstract interpretative art, but concrete constructive art," as Werner Haftmann notes: "Form and imago do not point to something else but signify only themselves. $" 46$

As the name implies, concrete art would become an important "intermediary genre" for the founding figures of concrete poetry such as Gomringer and the Noigandres poets, who, according to Greg Thomas, "encountered constructivist

${ }^{42}$ Daniel Herwitz, Making Theory/Constructing Art: On the Authority of the AvantGarde (Chicago and London: University of Chicago Press, 1993), 36.

${ }^{43}$ Kristine Stiles, Theories and Documents of Contemporary Art: A Sourcebook of Artists' Writings (Berkeley: University of California Press, 2012), 77.

${ }^{44}$ Ibid., 77.

${ }^{45}$ Rider, "The Concreteness of Concrete Art," 342.

${ }^{46}$ Werner Haftmann, Painting in the Twentieth Century Volume One, trans. Ralph Manheim (London: Lund Humphries, 1965), 338. 
ideals" through the concrete art "developed by a younger generation of artists including Max Bill and Josef Albers." ${ }^{47}$ The emphasis that artists such as Albers and Bill place on geometry and construction, Thomas suggests, "consolidated constructivist notions of efficiency of expression-colour, for example-with objective value" which the concrete poets would subsequently adapt and apply in terms of "syntactical and lexical construction.",48

The continuities of the non-figurative styles and theories of concrete with constructivism are made apparent in an early manifesto, "The Basis of Concrete Painting," co-signed by Van Doesburg, Otto Gustaf Carlslund, Jean Hélion, Léon Tutundijian, and Marcel Wantz and published in the sole issue of Van Doesburg's magazine Art Concret in April 1930. The manifesto begins by stating: "Art is universal." 49 This, a sentiment familiar to constructivism, presupposes that that there are universal principles and laws by which the universe is built and which are universally and objectively apprehensible." It is on similar grounds that Naum Gabo

${ }^{47}$ Greg Thomas, "The Tower of Babel: Concrete Poetry and Architecture in Britain and Beyond," in Spatial Perspectives: Essays on Literature and Architecture, eds. Terri Mullholland and Nicole Sierra (Bern: Peter Lang, 2015), 161-188, at 164.

${ }^{48}$ Ibid., 164.

${ }^{49}$ Otto Gustaf Carlslund, Theo Van Doesburg, Jean Hélion, Léon Tutundijian, and Marcel Wantz, "The Basis of Concrete Painting," in Van Doesburg and the International Avant-Garde: Constructing a New World, eds. Gladys Fabre and Doris Wintgens Hötte (London: Tate Publishing, 2009), 187. Gomringer would later express a similar conviction about concrete poetry, claiming: "concrete poetry is in the process of realizing the idea of a universal poetry." Gomringer, "Concrete Poetry," 68. 
and Antoine Pevsner state in their 1920 "Realistic Manifesto" that, "we construct our work as the universe constructs its own, as the engineer constructs his bridges, as the mathematician his formula of the orbits": "This is why we in creating things take away from them the labels of their owners ... all accidental and local, leaving only the reality of the forces in them." 50

Figurative representation is likewise repudiated in concrete art in favour of "direct and unmediated" encounters with the artwork itself. ${ }^{51}$ A painting, the Art Concret manifesto stipulates, "should not contain any natural form, sensuality or sentimentality" and should have "no other meaning than what it represents; consequently, the painting possesses no other meaning than what it is by itself." 52 Thus, in a concrete painting, Van Doesburg insists, "there is nothing to be read, but only things to be seen." ${ }^{, 53}$ Emphasis is placed on the autonomy of the painting, which

${ }^{50}$ Naum Gabo and Antoine Pevsner, “The Realistic Manifesto,” trans. Naum Gabo, in Russian Art of the Avant-Garde: Theory and Criticism, ed. John E. Bowlt (London: Thames and Hudson, 1988), 208-214, at 213.

${ }^{51}$ Alistair Rider, “The Concreteness of Concrete Art," Parallax 21, no. 3 (2015): 340352 , at 343 .

${ }^{52}$ Carlslund, Van Doesburg, Hélion, Tutundijian, and Wantz, “The Basis of Concrete Painting," 187.

${ }^{53}$ Theo Van Doesburg, cited in Haftmann, Painting in the Twentieth Century, 338. Van Doesburg's comment is echoed by Ronald Johnson, one of the few American poets to have ventured into concrete poetry (sometimes in collaboration with John Furnival), who makes a similar case for "seeing" rather than "reading" in his book of concrete poems, The Round Earth on Flat Paper. "Till recently, poetry, like prose, has been invisible," Johnson claims: "We can now make a line of poetry as visible as 
is not about the world but conceived as an object within it. Anticipating Williams's notions of economy and exactitude in The Wedge, and the linguistic structures of concrete poetry, concrete art, Van Doesburg contends, should be "precise rather than impressionistic," with "lyricism, dramaticism, symbolism and so forth" being firmly renounced in favour of the primary objective of the work: "clarity., 54

\section{Moschatel Press}

To return to McGann's references to "constructivism" in Black Riders, the "secondary status" of Morris's Kelmscott books invite comparison with this complex line of influence that leads from constructivism and concrete art to modernist and concrete poetry and eventually to the post-concrete poetics of Thomas A. Clark and Moschatel Press. In the case of McGann's reading of Morris, however, what remains especially salient from this historical perspective is the constructivist notion of truth to materials and the conviction, according to Herwitz, "that artworks are designed to actively and explicitly exhibit their mode of construction from simple geometrical elements, material, or color." 55

Clark's evocation of the Arts and Crafts Movement in relation to the Gloup both adumbrates and broadens these connections that McGann makes between Morris's typographical aesthetics and the formal innovations of "the constructivist line" in modernist literature. By way of Gimson and the Barnsleys, Clark highlights

a row of trees. We may see, not through, but with the letters." ${ }^{, 53}$ Ronald Johnson, The Round Earth on Flat Paper (Urbana, Ill; The Finial Press, 1968), n.p.

${ }^{54}$ Carlslund, Van Doesburg, Hélion, Tutundijian, and Wantz, "The Basis of Concrete Painting," 187.

${ }^{55}$ Herwitz, Making Theory/Constructing Art, 36. 
similar affinities between modern, avant-garde notions of making and constructionin literature and the visual arts - and the more traditional praxes of the Arts and Crafts Movement. In this respect, Clark tacitly identifies the Gloup's efforts with the synthesizing spirit of Walter Gropius’s Bauhaus.

It is, however, Clark's own work as a poet and, with the artist Laurie Clark, as publisher that makes these intersections between traditional craft and avant-garde making in modern poetry and publishing particularly salient. Although Moschatel has its roots firmly in the Gloup and the later phase of the international concrete poetry movement, it is also an important presence within the broader "Mimeo Revolution" that initially burgeoned in the 1950s when "Direct access to mimeograph machines, letterpress, and inexpensive offset made [...] publishing ventures possible, putting the means of production in the hands of the poet." ${ }^{, 56}$

Moschatel was one of the numerous small presses that, in the-late twentieth century, operated within a geographically capacious, yet close-knit and collaborative orbit of artist-poet-publishers. Some of the small presses that Moschatel shows affinity with included the Wild Hawthorn Press, Jonathan Williams's Jargon Society, Stuart Mills's and Simon Cutts's Tarasque Press, and the Coracle Press and gallery that Cutts established after the dissolution of Tarasque. ${ }^{57}$

Moschatel is reflective of the fertile intersections that occurred in the Mimeo Revolution and the broader contours of the New American Poetry, the British Poetry Revival, the international concrete poetry movement, Fluxus, mail art, and conceptual

\footnotetext{
${ }^{56}$ Steven Clay and Rodney Phillips, A Secret Location on the Lower East Side: Adventures in Writing 1960-1980, (New York City: Granary Books, 1998), 14.

${ }^{57}$ See Ross Hair, Avant-Folk: Small Press Poetry Networks: From 1950 to the Present (Liverpool: Liverpool University Press, 2016), 1-33.
} 
art. As well as participating in some of these lateral dialogues, the Clarks, with Moschatel Press, also took a "creative step backwards to join with the past" - to adopt an apposite phrase of Finlay's - that acknowledged the rural setting of the Cotswolds and its arts and crafts heritage as relevant factors in the development of their postconcrete poetics. $^{58}$

The Janus-faced outlook of Moschatel is particularly important for reconsidering what Thomas refers to as the "West Country concrete milieu" that Moschatel, in addition to the Gloup, was part of. ${ }^{59}$ If this milieu, as Thomas suggests, is "less easily pegged to suggestive narratives of geographically rooted cultural identity" than the activities occurring in Scotland and London at the time, then Moschatel's engagement with the region's strong arts and crafts tradition helped give this important pocket of concrete poetry a unique and enriching "geographically rooted" identity within the transnational networks and infrastructures of the Mimeo Revolution. $^{60}$

The intersections of concrete, constructivism, and craft in Moschatel publications are especially salient in the way they demonstrate and expand the ideas that McGann introduces in Black Riders concerning how imprints such as Kelmscott Press helped subsequent generations of "writers to explore the expressive possibility of language's necessary material conditions"—conditions that, McGann suggests, are

${ }^{58}$ Writing in 1966, Finlay claims: "I am not interested in 'experiment' but in avantgarde work which can take the creative step backwards to join with the past." Ian Hamilton Finlay, Selections, ed. Alec Finlay (Berkeley: University of California Press, 2012), xx.

59 Thomas, "The Tower of Babel," 181.

${ }^{60}$ Ibid., 181. 
"both broadly institutional (the publishing scene) and immediately physical (book design)." ${ }^{\prime \prime 1}$ If these conditions, as McGann proposes, were "taken up and extended by the modernists" including Laura Riding and Gertrude Stein then Moschatel Press, like the "best of [the] recent American poetry" that McGann cites, has also "assimilated and extended the bibliographical innovations passed on to us by the artists, poets, and crafts persons who labored so effectively through Pre-Raphaelitism, aestheticism, and modernism." ${ }^{62}$ Moschatel Press offers illuminating insight into the ways that "the material conditions" of language (institutionally and physically, to use McGann's terms) might dovetail with the Arts and Crafts Movement's commitment to "fundamentals in art and life, to truth to materials and to formal simplicity and purity" as they have manifested in the Cotswolds, in conjunction with the aspirational purity of the constructivist-concrete line of nonfigurative art that has impacted so purposefully on twentieth-century literature, art, and design. ${ }^{63}$

\section{Post-concrete}

Originally from Greenock, Scotland, Clark's own associations with the Gloup became more proximate when he and Laurie Clark settled in the town of Nailsworth in the early 1970s. Nailsworth, according to David Verey, is an "Ancient wool town with steep and narrow streets, a quantity of elegant Jacobean and Georgian houses, several

\footnotetext{
${ }^{61}$ McGann, Black Riders, 20.

${ }^{62}$ Ibid., 112.

${ }^{63}$ S. K. Tillyard, The Impact of Modernism: Early Modernism and the Arts and Crafts Movement in Edwardian England (London and New York: Routledge, 1988), 35-36.
} 
former cloth mills, Nonconformist chapels, and a seventeenth-century Friends' Meeting House."64

It was in one of the town's former mills, Days Mill, where the Clarks, in 1986, started the Cairn gallery that specialized in exhibiting minimal and conceptual art by, among others, Hamish Fulton, Richard Long, herman de vries, and Trevor Sutton. Prior to Cairn, in 1973, the Clarks founded Moschatel Press, which, in true cottageindustry spirit, they operated from their home, Iverna Cottage, in Rockness Hill on the outskirts of Nailsworth. ${ }^{65}$ Early publications included small booklets by Finlay, Jonathan Williams, and Cid Corman. However, notwithstanding several titles by Simon Cutts and, more recently, Matthew Welton, Moschatel has focused primarily on the Clarks' own work, much of which is collaborative and adopts a "mode of complementary presentation," as Robert Stacey describes it, "wherein the verbal image and the visual exist independently and yet interdependently." 66

A significant inspiration and model for Moschatel is the Wild Hawthorn Press. Started by Finlay and Jessie Sheeler (née McGuffie) in Edinburgh in 1958, Wild Hawthorn published a number of booklets and prints by an international range of modern poets and artists, including Lorine Niedecker, Robert Lax, Augusto de Campos, and Victor Vasarely. The press, however, became focused primarily on

\footnotetext{
${ }^{64}$ Verey, Shell Guide, 96.

${ }^{65}$ Nailsworth remained the Clarks' home until 2002 when they relocated to
} Pittenweem, a fishing village situated on the east coast of Scotland in Fife, where they continue to run both Moschatel Press and Cairn.

${ }^{66}$ Robert Stacey, “'Into the Order of Things': The Relations of Painting to the Poetry of Thomas A. Clark," in Candid Fields: Essays and Reflections on the Work of Thomas A. Clark, ed. Peter Dent (Devon: Interim, 1987), 24-36, at 29 
publishing Finlay's own work, which took the form of numerous postcards, booklets, and folding and standing cards. These and other simple yet innovative formats, as Clark notes, "exploited the spatial and sequential possibilities of turning pages in one small book" and explored "how meaning and nuance may be developed through presentation." ${ }^{67}$ In doing so, Wild Hawthorn publications have expanded upon some of concrete poetry's primary concerns: material expression, isomorphic form (structure as content), and the poem as autonomous object.

Finlay's influence on Clark as poet and publisher was both formative and enduring. "The first poet I ever met was Ian Hamilton Finlay," Clark claims, "and through him I came across 'concrete' poetry"':

Ian's was the first body of work I discovered which offered a different view of things to the Beats. Instead of a spontaneous outpouring, it was a very careful, small, meticulous making. It was the poem as an objective thing, the poem as a thing made. ${ }^{68}$

The material constraints and simplicity of the Moschatel card or booklet have provided Clark inexhaustible platforms for his own explorations of "careful, small, meticulous making" wherein form, format, and meaning are integral components of the "objective" poem.

${ }^{67}$ Thomas A. Clark, "Standing Poem Reclining," Poetry Review, 102, no. 3 (Autumn 2012), 57-59, at 58 .

${ }^{68}$ Thomas A. Clark, quoted in David Herd, "Making Spaces: An Interview with Thomas A. Clark," Oxford Poetry II, no. 3 (1993): 97-102, at 97. 
As a young poet, Thomas A. Clark had, according to Stuart Mills, "firmly aligned himself to the international Concrete Poetry movement." ${ }^{\text {"69 }}$ It was Clark's "youthful connection with the movement" that led him to visit the Cotswolds for the first time in the mid $1960 \mathrm{~s}$ in order to attend the Arlington-Une show. ${ }^{70}$ This formative pilgrimage was the result of Finlay initially having put Clark in contact with Houédard, which subsequently led to Clark forming close friendships with Cox, Furnival, and Verey; so much so, in fact, that when Verey moved to the Dorset town of Sherbourne in 1968 Clark joined him. There, Clark and Verey launched South Street Publications which published catalogues for later Arlington exhibitions such as Arlington Quadlog (1968) and Clark's little magazine Bo Heem E Um alongside titles by John Sharkey, Houédard, Clark, and Verey.

By the early 1970s, Clark, like Finlay, had "moved away from the concrete movement," but he continued to acknowledge its importance for giving him "“a greater appreciation of the value of the word as a thing-in-itself.", 71 Clark's contribution to the Experiments in Disintegrating Language / Konkrete Canticle LP is revealing in this respect. Unlike the other contributions-by the Konkrete Canticle group (Bob Cobbing, Paula Claire, and Michael Chant), Charles Verey, and Neil Mills - Clark's poems are not so much instances of "disintegrating language" as they are moments of what Clark himself describes as "Plain, unadorned speech" and "the

${ }^{69}$ Stuart Mills, Moschatel Press: Books, Cards, Prints by Thomas A. Clark and Laurie Clark. (Nailsworth: Moschatel Press, 1982), 1.

${ }^{70}$ Ibid., 1.

71 "Thomas A. Clark" author note, in Typewriter Poems, ed. Peter Finch (New York: Something Else Press, 1972), 45. 
fundamental poetic discipline of recognition." ${ }^{72}$ Thus, far from disintegrating language, Clark's poems distil it. "Some Flowers," for example, simply lists the names of a series of wild flowers and the dates of their identification:

July 21st: Iris

August 4th: Tufted Vetch

August 8th: Foxglove

August 9th: Stinking Mayweed ${ }^{73}$

"The form is easy but not lax," Clark remarks of this poem: "there is no grammatical padding — concise naming throughout" as it simply "notices and records.",74

The terse language of "Some Flowers" recalls classic early concrete poetry, particularly in its concern for what Eugen Gomringer calls the "restricted and simplified use of language"-for "concentration and simplification," "brevity and conciseness"-which Gomringer considers "the very essence of poetry.",75 Clark's poem also recalls the "constructivist line" that McGann notes in American poetry, particularly the "objectivist" stance of the late-modernist American poets admired by Clark such as Zukofsky (who was published by Wild Hawthorn Press and Openings Press). Indeed, in its eschewal of superfluous description, "Some Flowers" anticipates

${ }^{72}$ Experiments in Disintegrating Language / Konkrete Canticle, Arts Council of Great Britain AC 1971, LP, 1971, record sleeve notes.

${ }^{73}$ Thomas A. Clark, "Some Flowers," Experiments in Disintegrating Language, transcript.

${ }^{74}$ Ibid., record sleeve notes.

${ }^{75}$ Gomringer, "From Line to Constellation," 67. 
Ron Silliman's suggestion that Clark's poetry, which has "no room [...] at all for waste or inexact language," makes him "the closest thing Scotland has ever had to a true Objectivist."76

Elaborating on Silliman's claim, it is possible to see in the way that "Some Flowers" "notices and records" the concepts of "sincerity" and "objectification" that Zukofsky proposes in his essay, "An Objective." "Sincerity," Zukofsky writes, concerns "the detail, not mirage, of seeing, of thinking with the things as they exist, and of directing them along a line of melody" whereas "objectification" (which Zukofsky also calls "rested totality") denotes "the apprehension satisfied completely as to the appearance of the art form as an object."

Ray Di Palma evokes Zukofsky's terms in his gnomic appraisal of Clark's poetry: "Sincere. Sine cere. Without wax. No filler. Object. Ob jaceo. To throw against. A destination. Aimed at. Focus." 78 Echoing Clark's comment about "grammatical padding," Di Palma reaches a similar conclusion by way of an erroneous etymological speculation that "sincerity" derives from sine cēra ("without wax"). Accurate or not, Di Palma's reflections on the sincerity (sincērus) of Clark's poetics implicitly reiterate the clean, unadulterated, distilled sound of "Some Flowers" and its exacting Objectivist-like "Focus" on its subject.

76 Ron Silliman, “Thursday, June 09, 2005," Silliman's Blog, http://ronsilliman.blogspot.co.uk/200506 05 archive.html (June 9, 2005, accessed November 17, 2017).

${ }^{77}$ Louis Zukofsky, Prepositions +, 12-13.

${ }^{78}$ Ray Di Palma, "Some Notes on Thomas A. Clark," in The $L=A=N=G=U=A=G=E$ Book, eds. Bruce Andrews and Charles Bernstein (Carbondale and Edwardsville: Southern Illinois University Press, 1997), 212-214, at 212. 
The Objectivism of "Some Flowers" also extends to Moschatel Press itself. Not only is the botanical theme of "Some Flowers" elaborated by the name of the Clarks' press (which derives from the name of the woodland flower Adoxa moschatellina), the publications themselves provide apposite formats for Clark's longstanding concern for simple "easy" forms and what Zukofsky calls the "resolving of words and their ideation into structure."79

Moschatel Press was prompted by the gift of a treadle press that the Clarks received as a wedding gift in 1972. Finding the treadle too large, the couple replaced it with the popular small amateur letterpress, the Adana 8x5. Like the Arts and Crafts makers before them, the Clarks utilized "the positive and expressive qualities of limitation" that the letterpress imposed and, like Morris, worked "on the terms set by the medium itself." ${ }^{\prime 80}$ According to Clark, "using the press went with the concrete poetry sense of making rather than writing," which, he tells David Herd, "increased my sense of the material nature of a poem." 81 "The fairly severe limitations of the Adana have been a continuing influence on my poetry, as confining and as empowering as let's say, the haiku or the sonnet," Clark claims: "Publications are usually printed on standard papers, whatever is readily available. The pleasure is to be inventive, to play within the financial and material constraints." 82

\footnotetext{
${ }^{79}$ Zukofsky, Prepositions,+ 13.

${ }^{80}$ Tillyard, The Impact of Modernism, 30, 29.

${ }^{81}$ Clark, quoted in Herd, "Making Spaces: An Interview with Thomas A. Clark," 98.

${ }^{82}$ Thomas A. Clark, “An Inconspicuous Green Flower," in Certain Trees: The Constructed Book, Poem, and Object 1964-2006. Ed. Simon Cutts (Saint-Yrieix-laPerche: Centre des livres d'artistes, 2007), 143-144, at 143.
} 
Although ink-jet and digital printing have replaced the Clarks' initial Adana, their Moschatel publications continue to mainly take the form of small folding or standing cards, postcards, and booklets. Sewn binding (including stitched and Chinese binding) as well as extrinsic colour finishes and pasted covers are also not uncommon, all of which are done by hand. These publications, as Clive Bush notes, "seem the most appropriate form[s] for the poems whose patterns and structures nod towards the proverb, the saw, the dynamic and suspended statement of the haiku, the found poem from sign, the conversational exchange of rare readings.

The financial constraints of Moschatel contrast markedly with the handmade papers, specialist inks, and unique typefaces used by the Kelmscott Press. Size and means, however, do not detract from the press's exacting standards. One might compare what Mills describes as the "visual order, an unerring sense of design, and the insistence upon faultless printing" of a typical Moschatel publication to the chaste, sincere, production and design standards of Doves Press, which utilized clear typefaces and (unlike Morris's Kelmscott) minimal decoration. ${ }^{84}$ The focus on making (rather than writing), which Clark attributes to the influence of the Adana, and the material constraints that he and Laurie Clark have embraced, aligns Moschatel closely with the constructivist nature of Kelmscott Press. The scale of operation and the quality of materials might be different, but the care that the Clarks take with each publication draw notable parallels with "the craft and the art of making" that McGann identifies as a primary concern of Morris's Kelmscott editions.

${ }^{83}$ Clive Bush, Out of Dissent: A Study of Five Contemporary British Poets (London: Talus Editions, 1997), 61.

${ }^{84}$ Mills, Moschatel Press, 2. 


\section{The material poem}

A prime example of Arts and Crafts "making" intersecting with constructivist notions of "building" occurs in Clark's book A Still Life, published by Jonathan Williams's Jargon Society in 1977. This, Clark's second Jargon book, reprints several earlier Moschatel titles in conjunction with Ian Gardner's suite of black and white prints, Six Variations on a Chrysanthemum of William Morris. This tacit allusion to the Arts and Crafts Movement is further underscored by the poem that opens the first section of $A$ Still Life, "Words in a Garden":

Place words end to end as dry stones.

Using only local materials, arrange them sparsely to admit plenty of ventilation.

They will stand among the fiercest winds and keep the sheep out. ${ }^{85}$

With the emphasis on the placing and arrangement of words - rather than the writing or inscription of them-Clark reiterates his perception of constructivism as "a way of going about things, of fitting things together." ${ }^{86}$ The implicit context for such construction may very well be the rural art and craft traditions associated with the Cotswolds. Not only do the "local materials" suggest the distinctive limestone of the area that has traditionally been used for such practical purposes, but they also recall a general interest in the Arts and Crafts Movement for vernacular material and local craft traditions. Thus, the local method of dry stone construction provides an analogy

\footnotetext{
${ }^{85}$ Thomas A. Clark, A Still Life (Dentdale: The Jargon Society, 1977), n.p.

${ }^{86}$ Clark, quoted in Stacey, "'Into the Order of Things,"” 27.
} 
for how to construct a poem while also evoking the walls of a hypothetical garden. According to Sarah Rutherford, dry stone is the "characteristic walling" of Arts and Crafts gardens and an example of how material should "be in harmony with [its] locality, preferably sourced from close by as possible and worked in traditional ways." ${ }^{87}$ Indeed, the purpose of Clark's construction - to keep sheep and winds at bay-recalls the noted Arts and Crafts gardener Gertrude Jekyll who, in her book Some English Gardens (1901), writes of "large garden spaces with brick or stone for the defense from wild animals, and divided or encompassed with living hedges of yew or holly or hornbeam, to break wild winds." ${ }^{, 8}$

Despite his concrete-constructivist sympathies, "poetry is," according to Clark, "as far from a purely constructive art as it is from unselfconscious prose. It holds to the middle way between transparency and opacity, between the window and the wall," asserting both "its own fabrication and the promise of something beyond." ${ }^{\prime 9}$ Although Clark makes these assertions in the context of Finlay's early concrete poetry, Hamish Fulton's text-based art, and Thomas Joshua Cooper's photography, they also reflect his own poetics. It is, therefore, worth noting how Clark's dry-stone fabrication in "Words in a Garden" is ventilated (opened up) in order to counter vitiation. Consequently, the dry stone tacitly sustains the "promise of something beyond," even when that promise might pose a threat to its fabrication. In

${ }^{87}$ Sarah Rutherford, The Arts and Crafts Garden (Oxford: Shire Publications, 2013), $29,27$.

${ }^{88}$ Gertrude Jekyll, Some English Gardens (London: Country Life Library, 1901), 1.

${ }^{89}$ Thomas A. Clark, "Poetry and the Space Beyond," in Poiesis: Aspects of Contemporary Poetic Activity, ed. Graeme Murray (Edinburgh: The Fruit Market Gallery, 1992), 37-45, at 39. 
this respect, Clark's dry stone construction articulates how "Poetry does not deny a beyond but allows its proper distance. The respect it demands for its own substance it extends to other substances" whether that space beyond "is hospitable or inhospitable, remote or contiguous." 90 "To write a poem," therefore, "is not just to make an object which will take its place among other objects but to introduce a structure which will reorder and revalue the existing physical and psychic facts." 91

These relations between the constructed and the found, between human fabrication and the space beyond it, are also evident in the interventions that Clark's Moschatel publications make. Being "designed for the table or the mantelpiece, rather than the bookshelf," Clark explains to Glyn Pursglove, "had other implications, that somewhere one had to find words that would stand up to that amount of looking." $" 92$ Like a dry-stone wall, these publications must be resilient in order to stand by themselves and "have a life of their own in the world." 93 The materiality of a Moschatel publication emphasizes this resilience by conferring "a farther level of objectification":

The Objectivists insisted on the poem as a made thing, as a careful construction rather than an outpouring, while Concrete Poetry saw the poem as an object rather than a song. For me, working with a press is a farther level

\footnotetext{
${ }^{90}$ Ibid., 39.

${ }^{91}$ Clark, "Poetry and the Space Beyond," 45.

${ }^{92}$ Clark, quoted in Pursglove, "Thomas A. Clark," 15.

${ }^{93}$ Clark, “An Inconspicuous Green Flower,” 144.
} 
of objectification. Quite as much as consonants and vowels, different papers and typefaces can give weight and measure. ${ }^{94}$

"In a perfectly plain piece of work," the industrial designer and Arts and Crafts sympathizer Lewis F. Day writes in Every-day Art (1882), "a child can tell if the joints be inaccurate, the lines untrue, the surface unfinished. There are no flourishes to hide the faults." 95 The sincere candor of a Moschatel card implies a similar honesty. Like the Arts and Crafts object that, as Tillyard suggests, "should strive for simplicity and purity rather than gorgeousness of effect," the modest presentation of a Moschatel card leaves itself open to sustained or repeated looking. ${ }^{96}$

These qualities are apparent in Clark's folding card Metamorphosis, published by Moschatel Press in 1981 (figure 1), which conflates notions of organic and supernatural change with the objective rigour of concretist construction.

\section{[Insert figure 1 about here]}

A long narrow strip of manila card is folded into an accordion of six panels. Printed on the individual panels are, respectively, the words: "wind" / "flower" / "rock" / "rose" / "water" / "lily." With these six words Clark constructs the names of three flowers: "wind flower," "rock rose," and "water lily." Placed end to end like Clark's dry stone, the words are printed in an italic Bembo type: the elements of "wind,"

\footnotetext{
${ }^{94}$ Ibid., 143.

${ }^{95}$ Lewis F. Day, Every-day Art: Short Essays on the Arts Not Fine (London: B. T. Batsford, 1882), 174.

${ }^{96}$ Tillyard, The Impact of Modernism, 29.
} 
"rock," and "water" in a dark blue ink, and the botanical terms and names_- "flower," "rose," and "lily"-in a soft grey. Recalling Ovid's Metamorphoses, the title of Clark's card, Metamorphosis, is printed in blue on the small envelope that contains it.

Among its many stories, Ovid's poem, recounts how Adonis was turned into a windflower after having been torn apart by a boar; how the nymph Lotis was transformed into a lotus tree (which has sometimes been interpreted as a water lily or lotus flower); and how Lichas was petrified into rock. ${ }^{97}$ In Clark's card metamorphosis occurs in the kinetic presentation of the poem's words and in their fluctuations between nouns and verbs. With the accordion format creating a threedimensional relief, certain words are emphasized, and others hidden or obscured, depending on the position the card is viewed from. Consequently, elements morph into flowers; "water / lily," for instance, transforms a Lilium into a Nymphaeaceae. Likewise, nouns become verbs. For example, "flower" denotes both a plant and the process of development and blooming. It is, however, the very format - the material structure - of Metamorphosis that makes all of these suggestions and transformations possible. The card is not simply a passive vehicle for the poem but an integral component of its kinetic processes.

Display is therefore fundamental to Metamorphosis. In order to read the poem it must be put on view. Its laconic text and its simple card format jettison rhetorical or decorative embellishment and "refuses" what Clark describes as the "swift [...] transition from words to things." ${ }^{98}$ With the "bare bones" of the poem exposed, the eye slows down, stops, lingers. Consequently, like an Arts and Crafts object (or a

\footnotetext{
${ }^{97}$ See Annette Giesecke, The Mythology of Plants: Botanical Lore from Ancient Greece and Rome (Los Angeles: Getty Publications, 2014), 124-125.

${ }^{98}$ Clark, "Poetry and the Space Beyond," 39.
} 
concrete painting) there is a "shift away from representation to embodiment" as the card asserts its own physicality and presence as a made thing. ${ }^{99}$ In this way, the inconspicuous format of Metamorphosis, as well as being a condition of material and financial constraint, demonstrates Clark's "modest attempt to let poetry have a use, to bring it to the centre of everyday life, rather than keep it restricted to a separate realm, the literary, shut up between covers and relegated to the shelf." ${ }^{100}$ Modest or not, as a spatial intervention, a publication such as Metamorphosis extends how Morris "examined art, work and domesticity as inextricably bound up with the practice of everyday life under the prevailing conditions of production and consumption."101 Indeed, as a "work that both absorbs attention and stimulates the mind," Metamorphosis implies a similar 'call for a 'genuine' or 'pleasurable' interest in daily details" by reordering and revaluing (rather than simply ornamenting or furnishing) the space in which its poetics take place. ${ }^{102}$

\section{"without glory"}

The spaces of a Moschatel intervention are not, however, always domestic. "I like the way that our publications fall through the system yet exist in the world," Clark suggests:

\footnotetext{
${ }^{99}$ Tillyard, The Impact of Modernism, 21, 30.

${ }^{100}$ Clark, “An Inconspicuous Green Flower,” 143

${ }^{101}$ Wendy Parkins, "Introduction: William Morris and the Art of Everyday Life," in William Morris and the Art of Everyday Life, ed. Wendy Parkins (Newcastle Upon Tyne: Cambridge Scholars, 2010), 1-24, at 2.

102 Ibid., 5-6.
} 
They are to be found pinned to a notice board, carefully placed on a table, in a walker's jacket pocket, in galleries (or display cases in a library), rather than in bookshops. I like the fact that they get little acclaim but a lot of attention, that they are not given by the culture but a discovery for each person who comes across them. ${ }^{103}$

The way that one might find or discover these publications is not unlike discovering Moschatel Press's namesake, Adoxa moschatellina. However, it is not only the idea of happenstance and chance discovery that connects the press with botany. The modest nature of Moschatel publications - their lack of acclaim and their unassuming presence in the world-also recalls the root meaning of Adoxa moschatellina. "Adoxa means 'without glory,"' Heather Tanner (a late adherent of the Arts and Crafts ethos) writes in her book Woodland Plants. ${ }^{104}$ Although, Tanner stresses, "no green-flowered plant four inches high could be called glorious, this one can surely be described as unique."105

${ }^{103}$ Clark, “An Inconspicuous Green Flower,” 144

${ }^{104}$ Heather Tanner and Robin Tanner, Woodland Plants (London: Impact Books, 1992), 60. Heather Tanner's husband Robin was an artist, etcher, and engraver involved in the etching revival of the late 1920s which was sparked by the Samuel Palmer retrospective exhibition organised by Martin Hardie and F. L. Griggs at the Victoria and Albert Museum in 1926. Griggs's own etchings, Tanner claimed, "damaged me permanently, so to speak," particularly "the intense feeling" that Griggs showed for "Cotswold England." Robin Tanner, Double Harness: An Autobiography (London: Impact Books, 1987), 31.

${ }^{105}$ Tanner, Woodland Plants, 60 
Tanner goes on to describe the flower as "inconspicuous," an adjective that Alan Tucker also uses in his brief essay on the press: "If its manner is inconspicuous, it has sometimes been used as a symbol of watchfulness." ${ }^{\text {106 }}$ As Geoffrey Grigson explains, the reason of this watchful symbolism is linked to the local Gloucestershire name for the plant: "Town Clock."

The little terminal head of green flowers is well expressed by "Town Clock" or "Townhall Clock." Four green clock faces with yellow anthers stare out in four different directions. A fifth stares up into the sky. ${ }^{107}$

This local nomenclature can also be considered as another example of the Clarks' attention to local detail and material with the colloquial name, "Town Clock," evoking a distinctive landmark in Nailsworth, namely the war memorial clock tower, built in 1953 and designed by the Peter Falconer, son of the Arts and Crafts architect Thomas Falconer.

[insert figure 2 about here]

As a symbol of watchfulness, the moschatel flower is apposite for conveying the attention and care that the Clarks show for their subjects and for the care that they take in the production of their own work. Laurie Clark's line drawing of Adoxa

${ }^{106}$ Ibid., 60. Alan Tucker, "Moschatel Press," in Certain Trees: The Constructed Book, Poem, and Object 1964-2006, ed. Simon Cutts (Saint-Yrieix-la-Perche: Centre des livres d'artistes, 2007), 142, at 142.

${ }^{107}$ Geoffrey Grigson, The Englishman's Flora (Oxford: Helicon, 1996), 358 
moschatellina, an early pressmark for Moschatel, encapsulates such scrupulous attention to detail and careful observation (figure 2). Indeed, Clark's “inconspicuous" flower recalls how, as Les Arnold suggests, Clark's “objects speak only of the necessary line, the essential form" and are rendered "intensely as themselves" as if "seen for the first time." 108 These "essentials" might also be described in objectivist terms of sincerity, with "the perfect line" of Clark's drawing delineating the "detail, not mirage, of seeing.",109

The "sincerity" of Clark's drawing is fitting in the sense that the pressmark is as emblematic of Moschatel Press as it is its Adoxa moschatellina namesake. This is apparent in the way that the plant's form is conveyed, or carried over, in Clark's handwritten legend, "Moschatel Press," directly below the plant. Clark's scriptparticularly the bowl of the $\mathrm{P}$ in "Press" - repeats the cursive line of the single tailing root above it. Here Clark subtly bridges the graphic with the linguistic, reiterating the press's "mode of complementary presentation" and its collaborative spirit of written word and visual image. In this unassuming way, Clark's drawing makes its own "inconspicuous" statement about the nature of the press and the objectives of the work its impression is used to verify.

\section{Morning atmospheres}

Removed from the environment in which it occurs, Clark's drawing of the moschatel flower recalls the decontextualized specimens typical of botanical art and their purpose to convey "a generality" of a species' form and morphology "that ignores the

\footnotetext{
${ }^{108}$ Les Arnold, "Still Life: A Profile of Tom and Laurie Clark," The Green Book: A Quarterly Review of the Visual and Literary Arts 6 (1981): 3, at 3.

${ }^{109}$ Zukofsky, Prepositions,+ 12-13.
} 
imperfections of the individual specimen." ${ }^{110}$ However, as much as one might compare Clark's pressmark to the black and white drawings of a botanical artist such as, for example, Stella Ross-Craig who "combines sound botanical knowledge with sure draughtsmanship," it is the draughtsmanship of F. L. Griggs and his "incredible fineness of line" that Clark's work shows greatest affinity with. ${ }^{111}$

An architect by profession, Griggs turned to drawing and illustration after being inspired by the work of William Blake and a younger group of artists known as the Ancients, which included Samuel Palmer and Edward Calvert. ${ }^{112}$ In addition to these influences, Thomas A. Clark has noted the influence of the Arts and Crafts Movement on Griggs's work, which took proper hold after Griggs settled in Chipping Campden in 1903. There, Griggs "found the sympathetic fellowship of a group of men with tastes and ideals like his own," which included Gimson, the Barnsley brothers, and the Arts and Crafts architects Philip Webb and Norman Jewson. ${ }^{113}$ Between 1927 and 1937, Griggs designed and built his own house, New Dover's House, with fixtures and fittings made by the Sapperton group of craftsmen. As well

${ }^{110}$ Martyn Rix, The Golden Age of Botanical Art (London: Andre Deutsch, 2012), 8.

111 Wilfrid Blunt and William T. Stearn, The Art of Botanical Illustration (Woodbridge: Antique Collectors' Club, 2000), 294. Francis Adams Comstock, $A$ Gothic Vision: F. L. Griggs and His Work (Boston: Boston Public Library, 1978), 2. ${ }^{112}$ Ross Hair has discussed how Thomas A. Clark's poetry extends this tradition, noting a line of influence that extends from Blake and the Ancients, Griggs and Robin Tanner. More laterally, he notes how contemporary poets including Jonathan Williams, Ian Hamilton Finlay, Ronald Johnson, and Simon Cutts have also evoked this English visionary tradition. See Hair, Avant-Folk, 171-200.

${ }^{113}$ Comstock, A Gothic Vision, 9. 
as representing the pinnacle of the Cotswold Arts and Crafts Movement, the house also provided the location for Griggs's Dover's House Press, which reprinted Palmer's work and introduced it to a younger generation of etchers and printmakers, including Robin Tanner.

John Bevis situates Laurie Clark's drawings in the same visionary tradition that inspired Griggs, suggesting that in her work there is "a sense of the exuberance of nature we find in Samuel Palmer, which finds a perfect and inseparable accord with her husband's poetry, and a radiance entirely of its own."114 The comparison that Bevis makes to Palmer is most evident in Clark's topographical drawings in Moschatel publications such as By Footpath and Stile (1982), In A Country Churchyard (1983), and, with Thomas A. Clark, Pauses and Digressions (1982). The "radiance" of these drawings is a result of what Robert Stacey describes as Clark's "atmospheric line-and-stipple" effect. ${ }^{115}$

In one of the twelve prints comprising her folder of loose prints, By Foot Path and Stile, this technique endows a woodland river scene with a dappled, hazy pointillism, suggestive of Georges Seurat, that imparts an effervescent effect of the birch trees dissolving into air (figure 3).

[insert figure 3 about here]

The same technique achieves a different effect and mood in Clark's drawing of a garden scene for the cover of Pauses and Digressions (figure 4).

\footnotetext{
${ }^{114}$ Clark, quoted in Stacey, "“Into the Order of Things, "” 23.

${ }^{115}$ Stacey, "'Into the Order of Things," 29.
} 
[insert figure 4 about here]

The garden itself is evocative of the "garden rooms" typical of the Arts and Crafts gardens at Gloucestershire manors such as Hidcote, Snowshill and Rodmarton. In this particular drawing, Clark's line-and-stipple is more densely applied, giving emphatic volume and mass to the angular, clipped hedge centering the picture. By extending this textural quality to the natural forms of the surrounding shrubs and trees, Clark's stippling unifies the natural and the formal, conveying an ordered informality typical of the Arts and Crafts garden style and its reconciliation of the formal with the wild garden. In this respect, despite Bevis's comparison with Palmer, the clean geometrical lines of the clipped hedge in Clark's drawing - a rectangular form that is repeated in the drawing's frame and in the dry stone wall, formal pool, and steps-are more evocative of the architectural forms of Griggs's etchings.

Clark's cover for Pauses and Digressions invites particular comparison with Griggs's late etching Owlpen Manor (c.1930) which takes as its subject the Tudor manor house that his friend Norman Jewson, between 1925 and 1926, repaired from near dereliction. The house, however, is not as imposing as the "regiments of yews," as Jekyll and Lawrence Weaver describe them, which dominate the foreground of Griggs's etching. ${ }^{116}$ According to David Verey these trees are an integral part of the Cotswold landscape. "The romantic grey gabled manor house and its yew trees is," Verey writes, "a nostalgic symbol for anyone who has known and loved this part of the world and been separated from it." ${ }^{, 117}$ Although the yews in Griggs's etching

${ }^{116}$ Gertrude Jekyll and Lawrence Weaver, Gardens for Small Country Houses (London and New York: Country Life and Charles Scribner's Sons, 1914), xix.

${ }^{117}$ Verey, Shell Guide, 31. 
might, as Verey suggests, convey "the epitome of romance," they also express its increasing obsolescence and what Robert Meyrick calls Griggs's "lament" for a "long-lost rural England."118 Owlpen Manor is a prime example of how in the very romance of Griggs's rural English scenes - in his "loving delineation of a subject"there is, as Thomas A. Clark notes, a keen sense of "disintegration and loss" with "the very texture of Griggs's etchings [...] often darkening the tonal qualities to a profound melancholy.",119

Laurie Clark's tonal qualities, in comparison, are invariably lighter, possessing a soft, subtle splendor - a "simplicity and romance" as Thomas A. Clark describes it - that he identifies with his own poetry. ${ }^{120}$ This simplicity and romance, to recall Les Arnold's comment, suggests a way of seeing things as if for the first time, or what Thomas A. Clark calls a "nonjudgmental acceptance of the given." ${ }^{, 121}$ Rather than conjuring the nostalgia and melancholy of "a late time," as Griggs's tonal qualities do, the quality of the light that Laurie Clark's drawings radiate is akin to the rejuvenating luminescence of Thoreau's "morning atmosphere."122 The present moment, Clark's

${ }^{118}$ Ibid., 31. Robert Meyrick, "In Pursuit of Arcadia: British Printmaking in the 1920s," in Poets in the Landscape: The Romantic Spirit in British Art, ed. Simon Martin (Chichester: Pallant House Gallery, 2007), 59-82, at 60.

119 Thomas A. Clark, Silences of Noons: The Work of F. L. Griggs (1876-1938)

(Cheltenham: Cheltenham Art Gallery, 1988), n.p.

${ }^{120}$ Clark, quoted in Stacey, "“Into the Order of Things," 28.

${ }^{121}$ Clark, quoted in Herd, "Making Spaces," 102.

${ }^{122}$ Thomas A. Clark, "Pastorals," in Wood Notes Wild: Essays on the Poetry and Art of Ian Hamilton Finlay, ed. Alec Finlay (Edinburgh: Polygon, 1995), 152-55, at 152. 
topographical drawings imply, is an enduring, perennial one filed with promise and prospect.

\section{green thoughts / green shades}

Despite their tonal differences, Laurie Clark shares with Griggs an implicit conviction that, as Thomas A. Clark suggests of Griggs, "the natural and supernatural light are one." ${ }^{123}$ In this respect, Laurie Clark's work follows, like Griggs, in the line of Blake and Palmer. Quoting Blake and Palmer respectively, Clark conceives this as a tradition "in which our 'green and pleasant land' is a reminder of Eden" that affords "a glimpse of "the little dells, and nooks, and corners of Paradise.",124 Griggs's etchings, Clark implies, convey a visionary Platonic approach to this English topography. In "his search for the Ideal," Clark suggests, Griggs "presents us not with mere depictions but with images of English scenes [...] filtered through the transforming agent of his imagination."125

The "generality" of Laurie Clark's Moschatel pressmark, its depiction of the flower's eidetic form, suggests a similar aspiration for the Ideal. Thus, Clark's drawings suggest, to use Thomas A. Clark's phrase, the "timeless perfection" of that particular form. ${ }^{126}$ Indeed, Clark uses this term in relation to his early Moschatel poetry and its concern with a "Platonic doctrine of forms," which—preoccupying his

Henry David Thoreau, Walden, ed. Stephen Fender (Oxford: Oxford World's Classics, 1999), 82

${ }^{123}$ Clark, Silences of Noons, n.p.

${ }^{124}$ Ibid., n.p.

${ }^{125}$ Ibid., n.p.

${ }^{126}$ Clark, quoted in Pursglove, "Thomas A Clark," 18. 
work for approximately the first decade of the press's existence-is an annex of his longstanding, central concerns with the phenomenally experienced world. ${ }^{127}$

The "doctrine of forms," that Clark alludes to serves a set of formal concerns with purity that shares notable affinities with the universal principles of constructive and concrete art. Clark proposes that "a poet's job is not to see the particular, but to see it as a representative of its kind, to see behind it the platonic form": "One is returning to a timeless perfection, or attempting to get close to it," he tells Pursglove. ${ }^{128}$ To clarify his idea of a timeless "platonic" perfection, Clark offers the example of the daisy:

Not only the sense of a particular daisy, but of the daisy as a species, a necessary being, an eternal form. What one is attempting to capture is not so much the world of sense but that brightness beyond sense. ${ }^{129}$

${ }^{127}$ Ibid., 18. This phenomenological aspect informs a number of Clark's books including Sixteen Sonnets (Moschatel, 1981), In Praise of Walking (Cairn, 1988), and his three Carcanet titles: The Hundred Thousand Places (2009), Yellow and Blue (2014), and Farm By The Shore (2017). A similar distinction between platonic Ideas and the particular demarcates Laurie Clark's early and more recent work. Whereas Clark's Moschatel pressmark is concerned with the generality of a species, her two recent books published by WAX366, 100 Buttercups (2011) and 100 Harebells (2012), are concerned with the singular quality of each of the individual hundred specimens of buttercup and harebell that Clark has drawn.

\footnotetext{
${ }^{128}$ Ibid., 18.

${ }^{129}$ Ibid., 18.
} 
This "brightness beyond sense" is implicit in one of Clark's earliest Moschatel publications, The Garden (1973), which is also reproduced in A Still Life immediately following Clark's dry-stone poem in the section entitled "Words in a Garden." Clark's poem makes explicit allusion to Andrew Marvell's poem of the same name, abbreviating the final two lines of the poem's sixth stanza: "Annihilating all that's made / To a green thought in a green shade." ${ }^{130}$ The initial Moschatel edition of The Garden reaffirms this allusion to Marvell by printing the text in green ink. With its connotations of purity (freshness, tenderness, vitality, and innocence) Marvell's green thought, green shade conveys the garden as a place of repose and recuperation where "the unhampered creative mind is in perfect harmony with its vibrant natural surroundings." $" 131$

According to John Barrell and John Bull, Marvell's Garden is also “a paradise of the imagination, to be found by a turning inwards" that suggests "a world within a world and not a separation from it," and "a state of individual harmony that has no geographical placement." "132 The idea of "The Garden" as a utopian paradise of inner contemplation has also underscored numerous Neoplatonic readings of Marvell's poem, including Milton Klonsky's, which considers the garden figuratively as a

${ }^{130}$ Andrew Marvell, The Complete Poems, ed. Rev. Alexander B. Grosart (London: Robson and Sons, Printers, 1872), 63.

${ }^{131}$ Robert H. Ray, An Andrew Marvell Companion (Abingdon: Routledge, 2014), 78.

${ }^{132}$ John Barrell and John Bull, in The Penguin Book of English Pastoral Verse, eds. John Barrell and John Bull (Harmondsworth: Penguin, 1982), 147-148. 
"Garden of First Forms" and "a state of mind," wherein "the seeds of neo-Platonic Ideas are brought to a metaphysical bloom.",133

This is especially acute in the sixth stanza of "The Garden" where "shade" might mean both "a place not exposed to sunlight and a vital essence" or soul: ${ }^{134}$

Meanwhile the mind, from pleasure less,

Withdraws into its happiness;

The mind, that ocean where each kind

Does straight its own resemblance find;

Yet it creates - transcending these-

Far other worlds, and other seas;

Annihilating all that's made

To a green thought in a green shade. ${ }^{135}$

Like Plotinus' description of the soul's cognizance of the Divine Mind in the Enneads, the world of sense ("all that's made") in Marvell's poem is transcended via the annihilation of its sensible objects. "In this state of absorbed contemplation there is no longer question of holding an object," Plotinus writes: "seeing and seen are one thing; object and act of vision have become identical; of all that until then filled the

${ }^{133}$ Milton Klonsky, “A Guide Through The Garden,” The Sewanee Review 58, no. 1 (1950): 16-35, at 16 .

${ }^{134}$ Ibid., 17.

${ }^{135}$ Marvell, The Complete Poems, 62-63. 
eye no memory remains. ${ }^{136}$ Similarly, the green world of the garden in Marvell's poem is sublimated into no thing, but an insubstantial "green shade."

The horticultural allusions in The Garden convey similar notions of transcendence through contemplation by evoking the restorative properties of the garden space. As in Marvell's poem, Clark's garden is an undefined space where the world of sense gives way to "that brightness beyond sense." The Garden achieves this by means of Clark's post-concrete poetry which, Tony Lopez claims, "is composed in order to restrict context and expand resonance."137

In The Garden, however, context is not so much restricted as it is annihilated with only the poem's title and allusions to Marvell providing tangible context. What remains is a series of permutations that systematically elaborate Marvell's green thought, green shade:

green thought green shade

blue thought blue shade

yellow thought yellow shade

red thought red shade ${ }^{138}$

In the poem's garden, each colour-shade-thought implies a flower. However, lacking any identifiable referent, these pure colours also evoke the primary materials of nonfigurative concrete-constructive painting, especially Alexander Rodchenko's three

${ }^{136}$ Plotinus, The Ennneads. Trans. Stephen MacKenna (London: Penguin, 1991), 503.

137 Tony Lopez, “Thomas A. Clark, Nationality, Modernism," Scottish Literary Journal 20, no. 2 (Nov 1993): 75-85, at 76.

${ }^{138}$ Thomas A. Clark, The Garden (Nailsworth: Moschatel Press, 1973), n.p. 
intractable monochromatic canvases that reduce painting to its primary colors: Pure Red Colour, Pure Blue Colour, Pure Yellow Colour (1921). "Every plane is a plane," Rodchenko remarked of his triptych, "and there is to be no representation." 139 By this token, Rodchenko "reduced painting to its logical conclusion."

Clark's poem, however, tacitly challenges the purity of such logic and inadvertently recalls Hal Foster's contention that Rodchenko's triptych "demonstrate[s] the conventionality of painting" by defining "the fundamental properties of a given medium from within." 141 If Clark reduces representation to the three primary colours (and a secondary, green), he also reminds us that these primaries also form the basis of all other colours. Such reduction is, therefore, as much a starting point or promise as it is an end point or conclusion.

Progressing over the subsequent four stanzas, the poem's colour palette is mixed as Clark systematically permutes the initial stanza into all its possible combinations - "blue thought green shade," "yellow thought red shade," and so forth - to finally return to, and conclude with, a degression of the initial colour order:

red thought red shade

yellow thought yellow shade

blue thought blue shade

green thought green shade ${ }^{142}$

${ }^{139}$ Alexander Rodchenko, quoted in Hal Foster, The Return of the Real: The AvantGarde at the End of the Century (Cambridge, MA: The MIT Press, 1996), 17.

${ }^{140}$ Foster, The Return of the Real, 17

${ }^{141}$ Ibid., 17

${ }^{142}$ Clark, The Garden, n.p. 
Yellow, when mixed with blue, creates green. The poem thus concludes as it begins, with an impure, secondary colour. Semantically, however, "green" is, as previously noted, loaded with associations of purity and innocence. Likewise in Marvell's poem, as "a thought," Klonsky notes, "freed from any connection with the senses, 'all that's made' in this world, including passionate desire, becomes good, innocent, or 'green.",143

Thus, as well as gesturing toward the contemplative still life of the garden, The Garden also implies a level of kinesis due to the dynamic nature of its permuted colour scheme. As Winifred Dacre suggests, the reductive purity of colour in nonobjective painting is more an aspiration or ideal than a reality. "The nature of abstract colour is utter purity," Dacre writes, "but colours wish to fly, to merge, to change each other by their juxtapositions, to radiate, to shine, to withdraw deep within themselves." ${ }^{144}$ A similar kinesis of colour occurs in the geometric concrete paintings of Richard Paul Lohse whose "rigorous compositions appear to push beyond the edges of the canvas." ${ }^{145}$ Likewise, in his Interaction of Colour (1963), by means of the placement and juxtaposition of coloured sheets of paper, Josef Albers explores how "Colors present themselves in continuous flux, constantly related to changing

${ }^{143}$ Klonsky, "A Guide Through the Garden," 20.

144 Winifred Dacre, "Unknown Colour," in Circle: International Survey of Constructive Art, eds. J. L. Martin, B. Nicholson, N. Gabo (New York and Washington: Praeger Publishers, 1971), 57-60, at 59.

${ }^{145}$ Karl Ruhrberg, Art of the Twentieth Century Part 1: Painting, ed. Ingo F. Walther (Köln: Taschen, 2000), 227. 
neighbors and changing conditions." "146 The "green thought green shade" of the implied garden in Clark's poem might be understood in similar terms of relation and contiguity. Thus, "the framework of the garden" in Clark's poem attempts to compose the poem's restless colours - arranging and ordering them, as well as arresting and equilibrating them —in a place, as Marvell writes, "so pure and sweet."147

The implicit evocations of constructivist and concrete artists such as Rodchenko, Lohse, and Albers in The Garden are made more explicit in several subsequent Moschatel publications that build on Clark's earlier poem. In After Marvell and A Herb Garden, both of which Moschatel published in 1980, Clark expands the restricted colour field of The Garden by means of either the book format or its basic constituent parts. In addition, these particular publications elaborate on the implicit Platonism of The Garden by aligning that early poem more explicitly with Clark's belief, according to Mills, that "all modernist abstraction [is] Neo-Platonic in its aspirations." 148

Notwithstanding his claims about his own Platonic sensibilities, exactly what Clark (as reported by Mills) might mean by Neoplatonic aspiration is not clear. According to Mark Cheetham, Platonic and Neoplatonic ideas underpin the pioneering proto-abstract painting of Paul Gauguin, Paul Sérusier, and the Nabis, "not as a recondite philosophical system," but as "a living, driving force," which becomes more pronounced in the nonfigurative painting of Piet Mondrian and Vasily

${ }^{146}$ Josef Albers, Interaction of Color (New Haven and London: Yale University Press, 2013), 5.

${ }^{147}$ Marvell, The Complete Poems, 63.

${ }^{148}$ Mills, Moschatel Press, 4. 
Kandinsky. ${ }^{149}$ Broadly speaking, these artists have all strived for a hypostasis that, according to Plotinus, is "lapped in pure light and clear radiance [...] the original of which this beautiful world is a shadow and an image. ${ }^{, 150}$ Mimetic representations of this world do little more than duplicate these shadows and images and make no steps toward adequately reflecting or conveying the immutability of the Real.

In the De Stijl milieu of Mondrian and Van Doesburg the Neoplatonic aspirations hinted at by Clark find an equivalent in these artists' formal incarnations of "pure contemplative thought, pure innerness," which, according to Richard Padovan, hold to similar principals as Arthur Schopenhauer's conception of the "Platonic Idea." 151 Of particular significance in this respect is Schopenhauer's belief "that the visible world has only borrowed reality, and that only the Idea (or thing-initself) which is expressed in this world is truly real." ${ }^{\prime 152}$

Indeed, this theory poignantly adumbrates a quote from Plotinus's Enneads that Clark includes in a later Moschatel title, Three Colours: "Beauty perceived in natural things is beauty borrowed." ${ }^{, 153}$ Plotinus's notion of borrowed beauty recalls

${ }^{149}$ Cheetham, The Rhetoric of Purity, 9.

${ }^{150}$ Plotinus, The Ennneads, 247.

${ }^{151}$ Richard Padovan, Towards Universality: Le Corbusier, Mies and De Stijl (Abingdon: Routledge, 2001), 42.

${ }^{152}$ Hilde S. Hein, "Schopenhauer and Platonic Ideas," Journal of the History of Philosophy 4, no. 2 (1966): 133-144, at 135.

${ }^{153}$ Thomas A. Clark, Three Colours (Nailsworth: Moschatel Press, 1982), n.p. C.f. Plotinus in Ennead V, Tractate 9: "The guiding thought is this: that the beauty perceived on material things is borrowed." Plotinus, The Essential Plotinus, trans. Elmer O’Brien (Indianapolis, IN: Hackett Publishing Co., 1964), 47. 
Plato's disavowal of "relative" beauty in the Philebus, wherein Socrates explains the virtues of non-mimetic, self-possessing forms that do not borrow from or imitate nature:

By "beauty of shape" I don't in this instance mean what most people would understand by it- $-\mathrm{I}$ am not thinking of animals or certain pictures, but, so the thesis goes - a straight line or a circle and resultant planes and solids produced on a lathe or with ruler and square. [...] On my view these things are not, as other things are, beautiful in a relative way, but are always beautiful in themselves, and yield their own special pleasures quite unlike those of scratching. I include colours, too, that have the same characteristic. ${ }^{154}$

"Plato," as Haftmann remarks, "had been moved by the geometrical beauty that appears to us distinct from its logical causes and - because it had to be contemplated disinterestedly and without sensuous desire-it struck him as almost a moral value." "155 "This moralistic Platonism," Haftmann concludes, "provided the foundation for the aesthetics of the new Concrete Art" and adumbrated by "The "Constructivists and the Stijl artists [who] had already found the subtle beauty of geometry purer more stimulating than forms copied from visible nature."156

Echoing Plato's distinctions between "relative" and self-reflexive beauty—as well as the universal forms of Gabo and Pevsner's constructivist manifestoMondrian believes that "natural form and colour" conceal "the universal" whereas the

\footnotetext{
${ }^{154}$ Plato, Philebus, trans. J. C. B. Gosling (Oxford: Clarendon Press, 1975), 51.

${ }^{155}$ Haftmann, Painting in the Twentieth Century, 339.

${ }^{156}$ Ibid., 339.
} 
"universal plastic means" of "the straight line and determinate primary colour" can reflect more accurately and purely the forms of space and time that construct the universe. ${ }^{157}$ To recall the premises of the Art Concret manifesto, Van Doesburg would extend these ideas further by promoting the rejection of "any natural form" and endorsing instead a pictorial element that "has no other meaning than what it represents" in itself. ${ }^{158}$ In a similar spirit, Marvell's reduction of all resemblance in "The Garden" to a self-absorbing green thought in a green shade appears to possess no meaning other than what it is itself. The world of appearances is annihilated, giving way to pure, contemplative thought.

Clark's exploration of the relative qualities of colour in After Marvell is perhaps his most explicit evocation of this tradition of modernist abstraction and its tacit Platonic underpinnings and Neoplatonic aspirations (figure 5). Not withstanding the book's title, Clark jettisons words and reference entirely and works - not unlike Finlay in his 1965 kinetic booklet, Ocean Stripe Series 3-with the visual medium of colour in conjunction with the basic rudiments of the codex form.

[insert figures 5 and 6 about here]

Thus, After Marvell consists of nothing but blank leaves, hand sewn, in various shades of green. The ordering of the gathered leaves distributes these shades on the recto and verso of each page, creating a symmetrical order of progression and

${ }^{157}$ Mondrian, "Neoplasticism in Painting," in Manifesto: A Century of Isms, ed. Mary Ann Caws (Lincoln, NE: University of Nebraska Press, 2000), 425-428, at 426.

${ }^{158}$ Carlslund, Van Doesburg, Hélion, Tutundijian, and Wantz, "The Basis of Concrete Painting," 187. 
degression similar to The Garden. The gathering of pages establishes, according to Clark, a "simple ordering, a reverse form moving into the centre and out again" that, he claims, creates "the coherence of a formal garden." ${ }^{159}$ It also frames the composition.

Mills has also noted similarities between Clark's book and Marvell's "happy garden-state," suggesting that the reader should turn the pages of Clark's book "slowly, meditatively, giving sufficient weight to each shade and the green thought adjacent to it." ${ }^{\prime 60}$ After Marvell is, he claims, "a poem of retreat; the garden seen as a calming and steady influence." "161 And, like The Garden before it, Clark's book plays with the idea of composure. The calming and steadying influence of the garden, once again, becomes a mental space where the mind-like flowers or colours-are composed.

After Marvell is, according to Clark, one of several publications that attempt to "humanize a certain experimental or constructivist procedure by including it within a tradition of garden imagery and practice." 162 Clark's method of "making contemporary pieces with traditional materials" in After Marvell and, especially, $A$ Herb Garden, also recall the use of traditional materials in Arts and Crafts carpentry and garden design. ${ }^{163}$ Indeed, it seems apposite that in A Herb Garden Clark should temper the austere, rational strictures of pure nonobjective concrete art by substituting

${ }^{159}$ Clark, “An Inconspicuous Green Flower,” 143.

${ }^{160}$ Marvell, Complete Poems, 63. Mills, Moschatel Press, 3.

${ }^{161}$ Ibid., 3

${ }^{162}$ Clark, cited in Stacey, “'Into the Order of Things, "” 28.

${ }^{163}$ Mills, Moschatel Press, 3. 
its insistence on pure primary colors with a more nuanced spectrum of tones that evoke Jekyll's painterly sensibilities.

[insert figure 7 about here]

A Herb Garden extends the colour compositions of After Marvell by abandoning the latter's stitched codex format and utilizing instead single colored blank sheets of paper in varying shades of green, blue, and lavender (figure 7). These loose sheets, approximately A5 in size, are housed in a grey folder bearing the title In A Herb Garden. Printed in olive-coloured ink on an additional loose green sheet is the instruction: "To lay out yourself, using / Sage, Lavender, Thyme, / Rosemary, Balm \& Rue," followed by a quote from John Weathers's book, My Garden Book: Prepared for the Daily Use of All Who Own a Garden Big or Little (1924):

"All the materials for a picture are ready to hand, and it is now for the artist - in this case a gardener - to place his colours so that each shall shine forth in undiminished purity, without interfering or dimming the lustre of another, but rather that each colour shall be the complement of the other, and thus assist in creating in the bulk such a harmonious volume of pleasant tints as could not possibly be achieved in 
any other way.",164

Here, "gardener" and "artist" find common ground in Clark's sense of constructivism as "a way of going about things, of fitting things together." Indeed, Weathers's phrase "undiminished / purity" recalls the rhetoric of the constructivist line of art threaded through Mondrian's neoplasticism and Van Doesburg's concrete painting, while the emphasis on the placement of materials - as with Clark's dry-stone wall in A Still Life-would imply that this "picture" is an autonomous entity that stands for, and signifies, itself.

Haftmann considers "the rigourously constructed, geometrical paintings of Concrete Art" to be the "genuine products of meditation and contemplation" that "must be experienced meditatively, too, as icons in which intelligence contemplates the transparent structures of mathematical filigrees." ${ }^{165}$ While the humanizing imperative of Clark's construction tempers the mathematical rigour that Haftmann identifies, the loose sheets of A Herb Garden, which can be constructed either, as Mills suggests, "in the folder" or by setting them out "edge to edge," use colour as "meditative space." ${ }^{166}$ In this respect the loose sheets of coloured paper recall Albers's experiments in Interaction of Color, which are not only concerned with "seeing color" but also "feeling color relatedness" via "the interdependence of color with form and placement," and "pronouncement (by separating or connecting boundaries). ${ }^{167}$ Mills, however, upon seeing a framed composition of A Herb Garden

\footnotetext{
${ }^{164}$ Thomas A. Clark, A Herb Garden (Nailsworth: Moschatel Press, 1980), n.p.

${ }^{165}$ Haftmann, Painting in the Twentieth Century, 339.

${ }^{166}$ Mills, Moschatel Press, 3.

${ }^{167}$ Albers, Interaction of Color, 1-2.
} 
left him feeling "decidedly unnerved" when he discovered "it not to be a Lohse print. Much to the poet's amusement and delight." 168

\section{Tansy Buttons}

If the constructivist procedures of $A$ Herb Garden evoke nonobjective painting, then the herbs that Clark alludes to (Sage, Lavender, Thyme, Rosemary, Balm, and Rue) suggest the painterly concerns, the "beautiful garden-picture[s]," of Weathers's friend and dedicatee of My Garden Book, Gertrude Jekyll. ${ }^{169}$ Clark has claimed that his interest in flowers is primarily as "cultural objects"- "how people had seen these flowers in the past. The flower in history, as it were. ${ }^{, 170}$ It is worth noting, therefore, the cultural significance of the herbs evoked in A Herb Garden, particularly their medicinal, as well as their culinary, properties. A corollary of these beneficial effects might then be the manual activity of composing or "makin"g Clark's poem. Laying out the herbal colours becomes a restorative activity indissolubly linked to the Edenic image of the garden. Indeed, the conflation of the herbs with Weathers's aspirations for harmony echo Jekyll's garden ethos:

\footnotetext{
${ }^{168}$ Mills, Moschatel Press, 4.

${ }^{169}$ Gertrude Jekyll, Wood and Garden: notes and Thoughts, Practical and Critical, of a Working Garden (London: Longmans, Green, and Co., 1904), 196. Weathers
} dedicates his book "To my friend Miss Gertrude Jekyll, V.M.H. who by her writings has done so much to promote a love of gardens and gardening." John Weathers, $M y$ Garden Book: Prepared for the Daily Use of All Who Own a Garden Big or Little (London: Longmans, Green and Co., 1924), n.p.

${ }^{170}$ Clark, quoted in Pursglove, 16. 
I try for beauty and harmony everywhere, and especially of harmony of colour. A garden so treated gives the delightful feeling of repose, and refreshment, and purest enjoyment of beauty, that seems to my understanding to be the best fulfillment of its purpose. ${ }^{171}$

"The garden is artifice, harking back to Eden," Barbara Gates remarks of this, Jekyll's garden credo: "It is made to deliver us for a moment into a state of bliss [...] a place to which we can repair to restore ourselves." 172

Gates further suggests that "artistic arrangement, color, and composition were Jekyll's primary concerns" for achieving harmony. ${ }^{173}$ Colour, however, is also problematic due to the "irrelevance of comparison" that it elicits in garden writing and horticultural description. ${ }^{174}$ "Nothing is more frequent in plant catalogues than 'bright golden yellow,"” Jekyll writes, "when bright yellow is meant":

Gold is not bright yellow. I find that a gold piece laid on a gravel path, or against a sandy bank, nearly matches it in colour; and I cannot think of any flower that matches or even approaches the true colour of gold, though something near it may be seen in the pollen-covered anthers of many flowers. ${ }^{175}$

\footnotetext{
${ }^{171}$ Jekyll, Wood and Garden, 2.

${ }^{172}$ Barbara T. Gates, Kindred Nature: Victorian and Edwardian Women Embrace the Living World (Chicago and London: Chicago University Press, 1999), 189.

${ }^{173}$ Ibid., 192

174 Jekyll, Wood and Garden, 222.

${ }^{175}$ Ibid., 222.
} 
"Naming," as Gates notes, "has distanced [the gardener] from gardening." ${ }^{176}$ Voicing similar doubts as the constructivists and concretists about the inaccuracies of representation, Jekyll suggests that colours cannot, to recall Weathers, "shine forth in undiminished / purity" when they are abstracted by description. Indeed, Clark's innominate colours in A Herb Garden, their constructivist "efficiency of expression" to use Thomas's term, reiterate this concern with avoiding the kind of "reckless and indiscriminate use of [...] words" that Jekyll finds so problematic with gardening. ${ }^{177}$ Colours must, to use Jekyll's phrase, be "let alone" and unburdened of abstracting nomenclature. $^{178}$

[insert figure 8 about here]

Similar concerns about representation underscore another of Clark's Moschatel titles published in 1980, Tansy Buttons. The book's subtitle describes the poems as "Being the words of Gertrude Jekyll replanted in the manner of Gertrude

${ }^{176}$ Gates, Kindred Nature, 195.

177 Jekyll, Wood and Garden, 227.

${ }^{178}$ In chapter nine of Wall and Water Gardens, "When To Let Well Alone," Jekyll writes that, "In garden arrangement, as in all other kinds of decorative work, one has not only to acquire knowledge of what to do, but also to gain some wisdom in perceiving what is well to let alone" (63). Simon Cutts uses a plate with this caption from Wall and Water Gardens for the postcard (figure 8) promoting the Moschatel Press exhibition that ran at the Coracle gallery in Camberwell, London from late 1979 to early 1980. 
Stein." ${ }^{, 179}$ Clark takes playful advantage of the name that Jekyll shares with the author of Tender Buttons, Gertrude Stein. He also capitalizes on the colloquial name given to the herbaceous tansy plant (Tanacetum vulgare). Due to its hard, compact flower clusters, tansy is also known as "buttons" or "golden buttons." It is this aspect of the plant that Laurie Clark focuses on, depicting the top half of the plant's morphology in her line drawing on the book's title page (figure 9).

[insert figure 9 about here]

Complementing Laurie Clark's drawing is Clark's own "tansy button" about this particular flower:

Here is also Tansy. It is a plant that will grow. It is a plant that makes a considerable show. Hard yellow Flower. At the edge of pond or pool here is also Tansy. ${ }^{180}$

The proliferation of the letter "o," in conjunction with the long "o" rhymes of "grow," "show" and "yellow," provide visual and phonetic equivalents (rather than discursive descriptions) of the hard round flowers in Laurie Clark's drawing. Likewise, Clark's simple rhymes perfectly complement the equally simple, unpretentious lines of Laurie

\footnotetext{
${ }^{179}$ Thomas A. Clark, Tansy Buttons (Nailsworth: Moschatel Press, 1980), n.p. ${ }^{180}$ Ibid., n.p.
} 
Clark's drawing. Working together in this way, text and image tacitly evoke the honest design of the Arts and Crafts milieu in which Jekyll created her gardens.

The words that Clark "replants" in this "tansy button" are taken from Jekyll's book Wall and Water Gardens (1901). In her chapter "Small Ponds and Pools" Jekyll observes:

Here is also the Tansy, a plant that makes a considerable show with its large level-topped corymbs of hard yellow flower. It is a plant that will grow anywhere, but is especially luxuriant near water. ${ }^{181}$

Jekyll's words "At the edge of pond or pool" appear on the same page of Wall and Water Gardens but are used in reference to the Yellow Loosestrife (Lysimachia) and the purple Loosestrife (Lythrum).

Clark also liberally duplicates Jekyll's words to allow for repetitions that recall Stein's style. "I like the sense of repetition - the way that over quite a long paragraph [Stein] unravels the sense of a thing," Clark tells Pursglove. ${ }^{182}$ This emphasis on conveying "the sense of a thing," rather than directly describing it, underpins Tansy Buttons and its détournement of Jekyll's prose. Indeed, at the core of Tansy Buttons are considerations of representation and description that makes Clark's conflations of Jekyll and Stein — of tender and tansy "buttons"-more than punning name-play.

${ }^{181}$ Gertrude Jekyll, Wall and Water Gardens (London: Country Life Library, 1901), 115.

${ }^{182}$ Clark, quoted in Pursglove, "Thomas A. Clark," 14. 
Considering Clark's own painterly concerns in After Marvell and A Herb Garden, in addition to The Garden and A Still Life, it is apposite that Stein modeled her methods in Tender Buttons on the cubist still life. Jekyll, like Stein, was also interested in painting, albeit Turner, Hercules Brabazon Brabazon and Ruskin. Furthermore, Jekyll was herself a painter and, while a student at South Kensington School of Art, had studied Ruskin and Turner. It is not surprising therefore that Jekyll approached gardening "with a feeling for 'drawing' and proportion." 183

Jekyll's painterly concerns are the subject of one of Clark's "tansy buttons" in which Clark repeats a Stein-like imperative about how "the very best effects are made with the / simplest means":

It can never be repeated too often that the very best effects are made with the simplest means. It can never be repeated too often. Confused and crowded is a fault, a chance patchwork. We paint with living plants and the simplest means. It can never be repeated too often. ${ }^{184}$

Jekyll's phrases, from her chapter "The Rock-Garden" in Wall and Water Gardens, reiterate the Arts and Crafts emphasis on simple, honest design that uses "the /

${ }^{183}$ Jekyll, Wood and Garden, 268.

${ }^{184}$ Clark, Tansy Buttons, n.p. 
simplest means." ${ }^{185}$ Likewise, the aversion that Jekyll expresses for confused and crowded designs echoes the abhorrence expressed in Arts and Crafts design of ostentation, superfluity and the over-wrought. A "jumbled crowd of incongruous objects," Jekyll writes in the original text, "placed without thought of their effect on one another, can only make a piece of chance patchwork; it can never make a design." ${ }^{186}$ As well as a wry truism, Clark's repetition of "It can never be repeated too often" makes its own design by creating a repeated pattern or motif; not unlike the repetitions that occur in a Morris wallpaper pattern or in Jekyll's colour-graded plant schemes. And, like Stein, the effect of this repetition is of creating the sense of a thing — in this instance, the design of a Jekyll garden — rather than explaining or describing it.

Jekyll's claim that "We paint with living plants and the / simplest means" implicitly raises questions regarding representation and mimesis. Just as Picasso used real chair caning in Still Life with Chair Caning (1912), Jekyll uses real flowers in her compositions. Thus, with flowers no longer being the gardener-painter's subject, but their medium, one might ask just what it is that the gardener wants to "paint." For Jekyll, Gates writes, the garden "was the site of artistic intentionality, a construction that above all else called for a painter's eye," and through which "nature is not simply imitated but reinterpreted." 187 "Garden writing," furthermore, "gave Jekyll an alternative canvas on which to spread her colours" and another means for "transform[ing] the natural into the aesthetic." 188

\footnotetext{
185 Jekyll, Wall and Water Gardens, 90.

${ }^{186}$ Ibid., 90.

${ }^{187}$ Gates, Kindred Nature, 189, 190.

${ }^{188}$ Ibid., 192, 189.
} 
Clark's détournement of Jekyll's "painting in words" tacitly aligns her writing with the nonobjective painterly sensibilities and concerns of A Herb Garden and After Marvell. ${ }^{189}$ But Clark does so by broaching questions of abstraction, representation and mimesis from the perspective of Stein's literary constructivism (to recall McGann's term) rather than nonfigurative concrete or constructivist painting. Stein is a pertinent choice for framing these ongoing concerns of Clark's due to the way that Tender Buttons as Linda Voris suggests, makes a "radical break with conventional representation in a method that emphasizes the indeterminacy and materiality of language." ${ }^{190}$ Stein's "experiment with constraints of representation," Voris suggests, is underpinned by Stein's testing of “conventional propositional forms, including denotation, definition, and signification." ${ }^{\prime 191}$ The result, as Peter Nicholls suggests, are "verbal artifact[s]" that are "distinct from but related to the real." 192

Reflecting on the positive implications of a double-natured poetry, poetry that insists on its own fabrication and the promise of something beyond, Clark suggests that the "surfaces of poems are the more interesting for the faults and lacunae that occur in whatever limited autonomy poetry manages."193 Tansy Buttons provides a good example of such poetry. Although Clark never pushes Jekyll's language to the extremes of syntactical uncertainty that Stein does in Tender Buttons, his

\footnotetext{
${ }^{189}$ Ibid., 192.

${ }^{190}$ Linda Voris, The Composition of Sense in Gertrude Stein's Landscape Writing (Cham, Switzerland: Palgrave Macmillan, 2016), 100.

${ }^{191}$ Ibid., 102.

${ }^{192}$ Peter Nicholls, Modernisms: A Literary Guide (Berkeley and Los Angeles: University of California Press, 1995), 208.

${ }^{193}$ Clark, "Poetry and the Space Beyond," 39.
} 
"replantings" frequently destabilize her prose as the poems strain for a degree of "self-sufficiency" that proves to be unattainable: ${ }^{194}$

Speak of a blue. It must have sun

and air and full exposure. Its colour

may be said to be blue, a neat bushy

blue. It will thrive and flower

abundantly. ${ }^{195}$

The repeated pronoun "It" lacks a definite referent, and the determiner in "Speak of $a$ blue" is general rather than specific or particular. Consequently, the subject of Clark's poem remains unspecified. "Blue" might suggest a flower (perhaps the Romantic blue flower of Novalis), a colour, or a mood. The requisite of sun and air also might evoke plein air painting, and "full exposure," perhaps photography. Furthermore, the break of the first line at "sun" connotes the blue of azure skies. However, such a reading is impeded by the autonomy of Clark's paratactic sentences that, collectively, refuse to cohere into linear meaning. As in the design of a garden, meaning and effect is created by indirect suggestion and by arrangement, proximity, and contiguity. Like Jekyll's use of colour in the garden, "the most powerful and brilliant effects" of Clark's words are the consequence of "relation and proportion," of how one thing might relate to another. ${ }^{196}$ Thus, the surface of the poem refuses to yield a deeper meaning.

\footnotetext{
${ }^{194}$ Ibid., 39.

${ }^{195}$ Clark, Tansy Buttons, n.p.

${ }^{196}$ Jekyll, Wood and Garden, 268, 269.
} 
"As far as Clark is concerned," Mills stresses, "flowers, landscapes, gardens etc. are merely images or motifs upon which to expand": "The work is not about flowers or landscapes or gardens in the same way that Juan Gris' The Washstand of 1912 is not about a washstand." ${ }^{, 197}$ Mills's comments are applicable to Tansy Buttons. Without a flower being explicitly referred to (only inferred by context), Clark's poem draws attention to its words and the nature of their relations. We might, for example, notice the contrast of the imperatives "must" and "will" with the more flexible "may." Another imperative, "Speak," and the related word "said," are also notable, implying that the "blue" in question is perhaps a spoken one. A blue made manifest, a blue that thrives and flowers, by speaking and saying: "blue." The homophone of blue and blew-another oral gesture-also announces itself in this context. Thus, like Mallarmé's absent flower, this particular "tansy button" might be "a pure notion" that is only realizable in language:

What good is the marvel of transposing a fact of nature into its almost complete and vibratory disappearance with the play of the word, however, unless there comes forth from it, without the bother of a nearby or concrete reminder, the pure notion.

I say: a flower! and outside of the oblivion to which my voice relegates any shape, insofar as it is something other than the calyx, there arises musically, as the very idea and delicate, the one absent from every bouquet. ${ }^{198}$

\footnotetext{
${ }^{197}$ Mills, Moschatel Press, 1.

${ }^{198}$ Stéphane Mallarmé, "Crisis in Poetry," trans. Mary Ann Caws, in Stéphane Mallarmé: Selected Poetry and Prose, ed. Mary Ann Caws (New York: New Directions, 1982), 75-76.
} 
However one might read it, what in Jekyll's text is a direct reference to a Gromwell flower (Lithospermum) is, in Tansy Buttons, indirect and less tangible or specific. This is perhaps the principle difference between Jekyll's garden writing and Clark's Steinian appropriations of it. Jekyll may, as Gates suggests, invoke the "image, not reality" of a garden through a "sense of immediacy that represents her having been in this place at this time," however, in this particular replanting of her prose, even that illusion gives way to the words that have constructed its image. ${ }^{199}$ In comparison to Jekyll's subject, Clark's "blue" is a "brightness beyond sense," a pure notion, or an eternal, eidetic form that is only present in the arrangement of Jekyll's words. Thus, in his conflation of Arts and Crafts garden writing and McGann's "constructivist line" of modernist poetry, Clark returns to the representational concerns of nonfigurative painting and what he considers a "heroic moment" in modernist art when "art was able to liberate itself from subject matter and draw attention to itself as an activity."

Where Jekyll strategically arranges colours, Stein arranges words. In both instances, there is an emphasis on the placement of material and the indirect selfreflexive associations that those arrangements elicit. In the case of Clark's replanting of Jekyll's words, the more they recede from the exterior world of reference and sense - the more removed they are from "the bother of a nearby or concrete reminder"- the more objectified they become. This "objectification," to recall Zukofsky's phrase (and Clark's use of it), draws attention to the words themselves as presences, as things, rather than as transparent signifiers to be looked through.

\footnotetext{
${ }^{199}$ Gates, Kindred Natures, 194, 193.

${ }^{200}$ Clark, quoted in Stacey, "“Into the Order of Things," 27.
} 


\section{Conclusion}

Via Jekyll's prose, Clark achieves an effect similar to what McGann calls Stein's "nonreferential" writing and her "linguistic (as opposed to bibliographical) procedures for bringing the reader's attention back to the text's literal surfaces and immediate moments." ${ }^{201}$ Indeed, Tansy Buttons is, relatively speaking, not an overtly visual publication. Only Laurie Clark's line drawing and the booklet's large san serif type give the publication visual emphasis. Nevertheless, Clark objectifies Jekyll's prose by imposing on it, to cite from another "tansy button," "a practice of the most severe restraint." ${ }^{202}$ In doing so, Clark's Tansy Buttons assume a materiality that, like Morris's Kelmscott editions, makes its words "objects or images in themselves" and "values in themselves (rather than vehicles for delivering some further value or meaning).",203

Peter Quartermain indicates what might be at stake in such self-reflexive, objectified publications as Tansy Buttons when, like McGann, he considers the institutional and physical implications of small press publishing and the "the power of the book as an intellectual construct, as an authority."204 Indeed, Quartermain presents Moschatel as one recent example of "a long history in this century of editors and writers deliberately violating bibliographic decorum, or indifferent to it." 205 What the Clark's have done through Moschatel, according to Quartermain, is foster

${ }^{201}$ McGann, Black Riders, 21-22.

${ }^{202}$ Clark, Tansy Buttons, n.p.

${ }^{203}$ McGann, Black Riders, 75.

${ }^{204}$ Peter Quartermain, "Undoing the Book," Text 9 (1996): 119-132, at 120.

${ }^{205}$ Ibid., 124. 
"meaningful systems-violations in the production of the written and printed word" that oppose the institutionalized authority of "the book" and its culture:

The central passionate desire of the bibliographic enterprise, surely, is, through complex acts of critical and physical description, to stabilize the text and its provenance (including authorship and the means of production), and by extension therefore to stabilize the visible and the invisible, the material and the immaterial world, by rendering it subject to description and thus to control: that is, as painlessly as possible to absorb the work into the culture. ${ }^{206}$

Moschatel publications not only violate bibliographical convention by destabilizing nomenclature and categorization but they also destabilize those normative binaries that, as Quartermain suggests, constitute and stabilize "the culture." Like Rodchenko with his pure paintings, the Clarks have resisted the given culture by working with their printed medium from within, challenging the codes and values inscribed by conventional "bibliographic enterprise."

The anonymous author of an essay written to accompanying an exhibition of Moschatel publications at the University of Durham in 1996 suggests that the Clarks' imprint reconciles "the dichotomy and conflict between the small press and the fine press" and promotes "the possibility of a private press enlarged." ${ }^{207}$ It does so, the author proposes, via "texts and design" that "offer a way forward from the taste and

${ }^{206}$ Ibid., 119.

${ }^{207}$ Moschatel and Morning Star: The Private Press Enlarged (Durham: University Library, 1996), 23. 
practice of the traditional fine press." ${ }^{208}$ There is, evidently, a paradox that a small press as modest and inconspicuous as Moschatel should enlarge the pioneering efforts of a fine press such as Kelmscott. As importantly, however, Moschatel Press has also enlarged the Cotswold Arts and Craft tradition and reasserted its emphasis on craft and construction in terms of publishing that can enrich the commonplace and everyday. "The means can become creative," Clark suggests: "Everything can be exact but also light, since production is a way of life, an activity rather than an occasion. $" 209$

\section{Acknowledgements}

I would like to thank Thomas A. Clark and Laurie Clark for providing me material and images and for assisting with my enquiries. I would also like to thank Colin Sackett for the providing me the images of After Marvell and A Herb Garden.

\footnotetext{
208 Ibid., 23.

${ }^{209}$ Clark, “An Inconspicuous Green Flower,” 144.
} 